\title{
Teratogens and craniofacial malformations: relationships to cell death
}

\author{
K. K. SULIK ${ }^{1,2}$, C. S. COOK ${ }^{1}$ and W. S. WEBSTER ${ }^{3}$ \\ Departments of 'Anatomy, ${ }^{2}$ Ophthalmology, Universtty of North Carolina, Chapel Hill, NC 275/4, USA \\ ${ }^{3}$ Department of Anatomy, University of Sydney, Sydney, Australia
}

\section{Summary}

Environmental agents including ethanol, 13-cis retinoic acid (RA, Accutane ${ }^{\bigotimes}$ ), the antimetabolite methotrexate, periods of hypoxia, ionizing radiation or hyperthermic stress, when administered acutely to pregnant experimental animals, induce stage-dependent craniofacial malformations comparable to those in corresponding human teratogen syndromes. Acute treatment regimens have allowed analysis of cell populations initially affected and subsequent dysmorphogenetic sequences as well as speculation relative to mechanisms of teratogenesis. In rodent models, ethanol and RA appear to affect similar cell populations and comparable malformations can be induced by both agents. When administered during gastrulation they cause a major insult to the anterior neural plate which results in characteristic ocular, brain and facial malformations comparable to those seen in the fetal alcohol syndrome. Exposure to these drugs at a time just prior to and during neural crest cell migration into the craniofacial and cervical regions results in malformations comparable to those seen in the DiGeorge sequence and/or retinoic acid embryopathy. Slightly later, at the time that the epibranchial placodes are active, insult results in mandibulofacial dysostosis-like syndromes. We propose that the pattern of these malformations is related to the particular vulnerability of cells in the vicinity of normal programmed cell death. Cell death is also associated with ionizing radiation and hyperthermia-induced malformations. Both of these teratogens are particularly damaging to the early development of the eye and central nervous system. Teratogenic temperature elevations result in arrest of mitotic activity and death of cells in mitosis. Hypoxia is also associated with cell death in specific regions and subsequent malformation. For example, death of cells in the invaginating olfactory placode has recently been associated with cleft lip formation. The relationship of hypoxiainduced cell death to energy requirements is being explored. Acute treatment with methotrexate results in frontonasal dysplasia (median facial clefts). Combined effects of fluid imbalance, lack of proliferation or death of frontonasal mesenchyme appear to be involved. Although the mechanisms of craniofacial malformation are complex, a common feature for many is excessive cell death for which the embryo may be unable to compensate. Excessive cell death in regions of programmed cell death represents an important, yet little appreciated, mechanism of teratogenesis.

Key words: animal models, cell death, craniofacial malformation, ethanol, hyperthermia, hypoxia, ionizing radiation, methotrexate, retinoic acid, teratogen.

\section{Introduction}

This review is designed to provide the reader with an understanding of the genesis of craniofacial malformations which result from insult during the embryonic period. Alterations initiated in the fetal period are not considered. Particular emphasis is placed on the effects of teratogens of human significance which have been studied in our laboratories. Recent reviews by Johnston \& Sulik (1984) and Sulik \& Schoenwolf (1985) are recommended as broader overviews of normal and abnormal craniofacial development. Although the bulk of this paper is organized under the headings of the various teratogens considered, we wish to point out that there is considerable overlap in the types of malformations that can be induced in 
animal models by different environmental agents as well as by genetic factors.

We have directed much of our discussion toward pathogenetic mechanisms. Although interference with any number of developmental events (e.g. mitosis, cellular interactions, protein synthesis, cell migration) could result in dysmorphogenesis, herein we will focus on the role of cell death in craniofacial malformation. We recognize that other teratological processes may be previous to or simultaneous with cell death. Additionally, necrosis is more easily detectable than other teratological processes which may create a bias in interpretation of experimental results. It is also important to note that many cytotoxic, teratogenic agents produce cell death in tissues which can appear normal at birth.

\section{Cell death in craniofacial teratology}

Cell death is a common feature seen in embryos after exposure to a variety of teratogens that induce craniofacial malformations. It is well established that the sites of cell death vary depending upon the teratogen (or genetic insult) and the exposure time (i.e. developmental stage of the embryo). However, the question of why, in response to a cytotoxic agent, some cells die and others do not has received little attention. As pointed out by Scott (1977), "the sparing of some cells is probably necessary for the production of malformations since, if all tissues were severely affected, the embryo would probably die. On the other hand, if cell death were uniform but not severe, the embryo would probably develop normally or be retarded in growth but not structurally malformed". Speculation relative to selective sensitivity has focused on proliferative activity; i.e. tissues with high proliferative activity are more likely to show cell death than those that proliferate more slowly. It has, however, been shown that there are cases where other factors, e.g. state of cellular differentiation, differential drug distribution, or other specific cellular characteristics are involved (reviewed by Scott, 1977).

Of particular interest for this review is the relationship of cell death associated with teratogens and normal physiological or programmed cell death (PCD). Menkes, Sandor \& Ilies in their 1970 review of cell death in teratogenesis state that both the disappearance and expansion of areas of PCD, either experimentally induced or spontaneous in origin, may have a role in teratogenesis. They note that many areas of PCD are localized in territories with a marked incidence of anomalies. Pexieder (1975) also realized the significance of this phenomenon, hypothesizing that PCD zones in the heart represent a common target for both haemodynamic and chemical teratogens.

Schweichel \& Merker (1973) described three morphologically distinct types of PCD as follows. Type 1 involves cellular condensation, fragmentation. phagocytosis and secondary lysosomal degradation. Type 2 is characterized by the initial appearance of large cytolysosomes followed by cellular disintegration. Type 3 occurs without the lysosomal system and without apparent phagocytosis. The necrotic cells fragment into small portions that become undetectable at the light microscope level. These investigators proposed that teratogens which disturb DNA replication, transcription and messenger RNA translation will cause an increase in the number of cells undergoing type 1 cell death, whereas agents that labilize lysosomes would be expected to increase type 2 cell death. Some substances, such as vincristine, that block mitosis were found to result in necrotic cells which are morphologically distinct from those undergoing PCD.

Glücksmann's (1951) pioneering work points out the importance of cell death in normal development. His research in several classes and species of vertebrates showed the existence of many transitory delimited necrotic areas during organogenesis. Studies of necrotic areas in mouse, rat, rabbit and human embryos described in a number of publications by Menkes. Ilies and coworkers (Menkes, Litvac \& Ilies, 1964; Menkes, Deleanu \& Ilies, 1965; Ilies, 1967, 1969) provided further data illustrating the presence of several homologous necrotic areas in these species as well as some interspecies variations in localization and intensity of PCD. The description of necrotic areas in human embryos ranging from 3 to $30 \mathrm{~mm}$ is particularly valuable. In the human craniofacial region, necrotic areas were described in the cranial nerve ganglia, in the olfactory placodes and subjacent mesenchyme, in the optic vesicles, lens placodes, otic placodes, and in the mesenchyme of the first and second visceral arches (Ilies, 1967).

Fig. 1. Nile Blue Sulphate (NBS) uptake. (A) Cellular debris and cytolysomes of an E7 mouse embryo.

(B) Phagocytes of an E10 mouse embryo. Large phagocytes such as these are apparently not present on E7 and E8. (C) An E7 gastrulating embryo, staining is localized to the neural plate. Note absence of staining in the region of the primitive streak (arrow). (D) An 11 -somite E8 embryo, staining is present in the dorsal aspect of the rhombencephalic neural folds (arrow). A $1 \mu \mathrm{m}$ section through this area of a comparably staged embryo shows cellular necrosis (E). The crest of the neural folds around the developing fourth ventricle shows heavy NBS uptake in this control 13-somite embryo (F). 

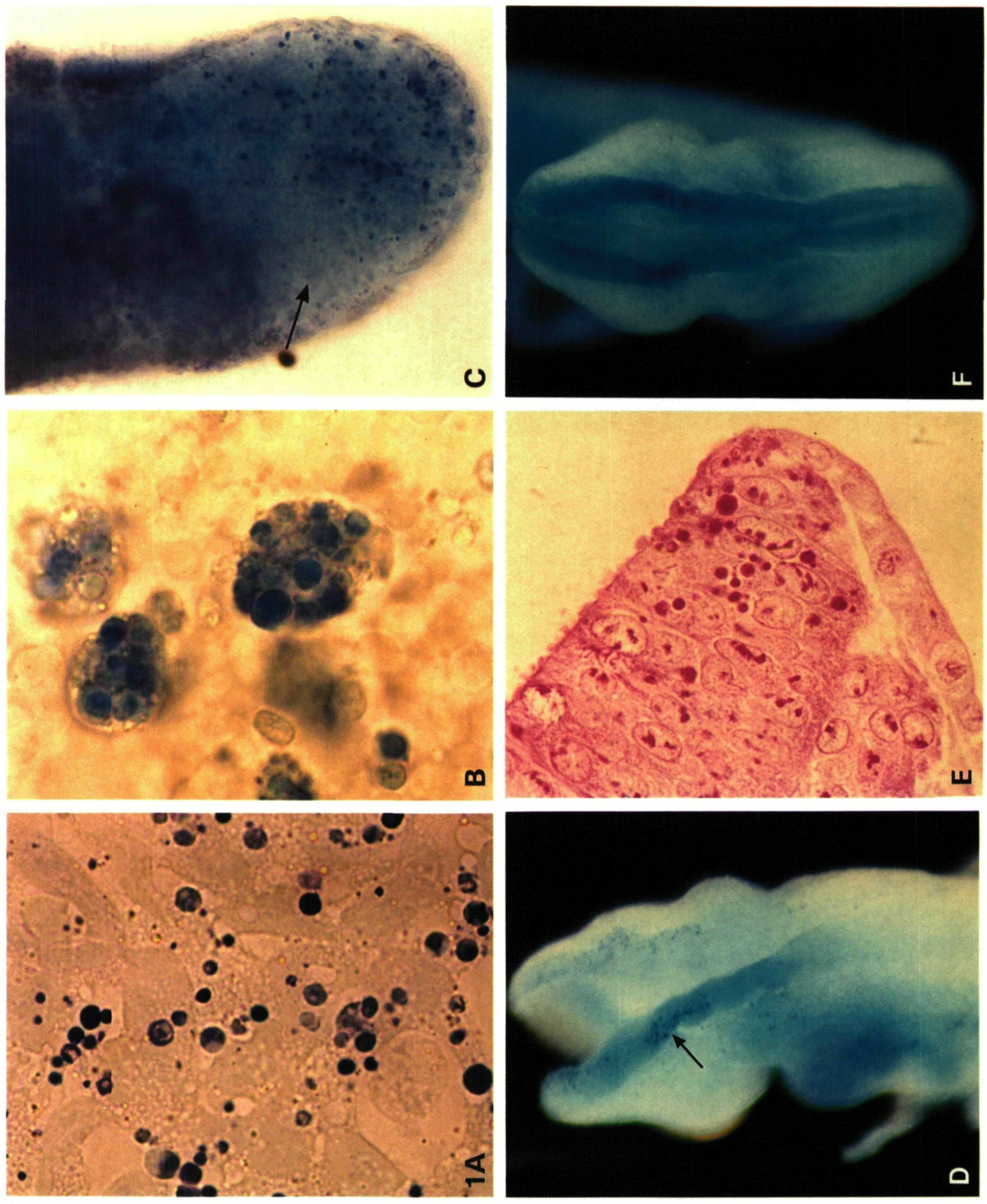

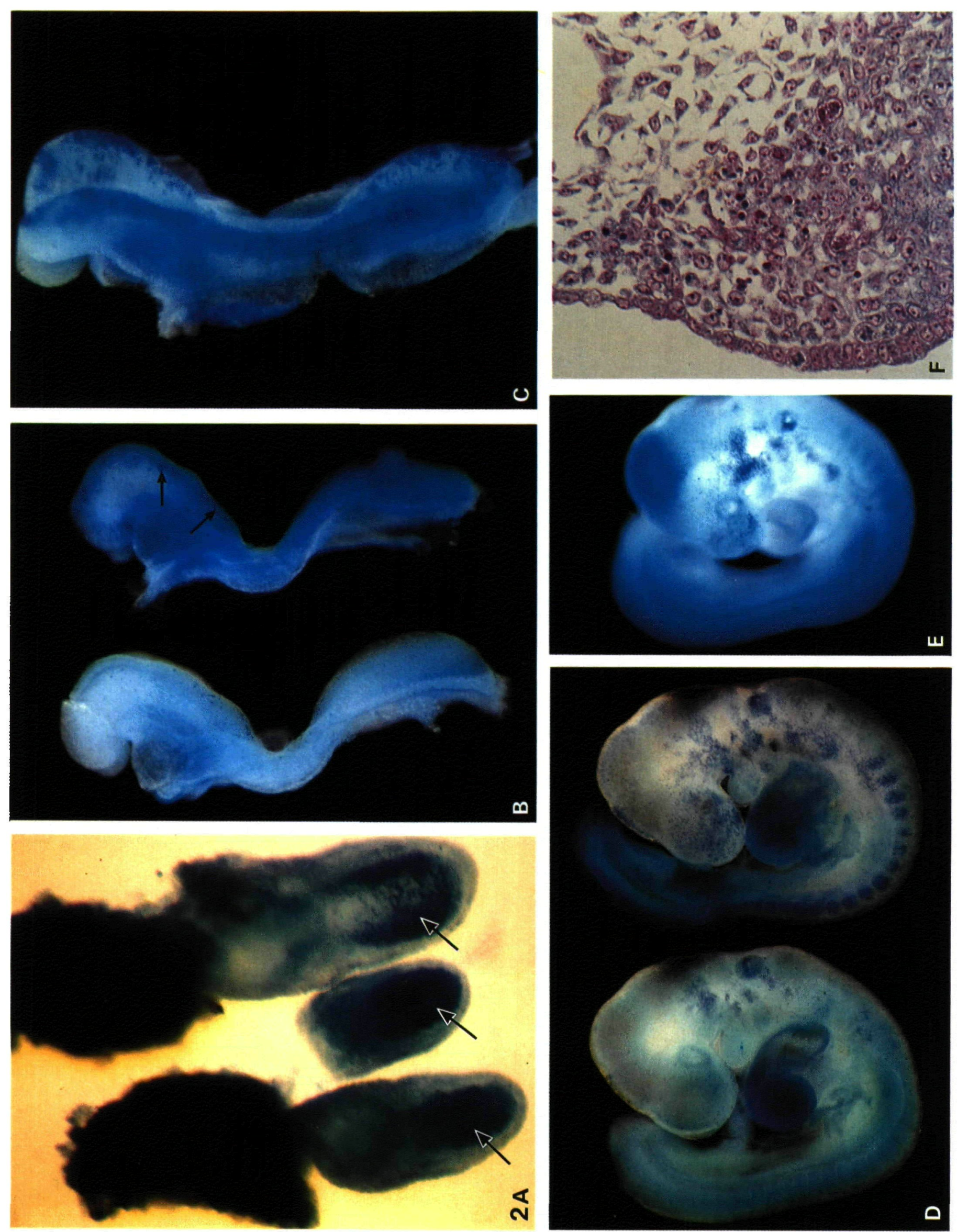
Studies in our laboratories involving acute exposure of mouse embryos ranging from early gastrulation stages through approximately 35 somites to human teratogens have directed our attention toward the relationship between teratogen-induced cell death and normal PCD. Comprehensive descriptions of patterns of normal PCD at these early stages in the mouse are apparently lacking. As teratogenic agents may produce an extension of $\mathrm{PCD}$ areas or create unusual necrotic areas, maps of locations of PCD for the species being studied are necessary in order to avoid confusion between normally occurring PCD and the teratogenic action of the agent being tested. Consequently, we have initiated studies to investigate this in mouse embryos using supravital Nile blue sulphate (NBS) staining. Exposure of whole live embryos to dilute solutions of this stain results in intense uptake in regions which in histological sections contain numerous necrotic cells (Saunders, Gasseling \& Saunders, 1961). Unfortunately, NBS is not retained in tissues prepared for routine histological sections.

Although knowledge of the exact mechanism of staining of necrotic cells by NBS is lacking, Pexieder's studies (1975) indicate that the stain is concentrated in cytolysosomes and in phagosomes where cellular debris is uniformly stained (Fig. 1A,B). Assuming that the mechanism of staining is similar to that of neutral red for which NBS has similar physicochemical properties (Pexieder, 1975), this compound accumulates in lysosomes due to the fact that it is lipophilic and weakly basic. Therefore, it is readily able to enter lysosomes or dead cells where lysosomal enzymes have been released and it becomes trapped by protonation (Ohkuma \& Poole, 1981).

The strain of mice used in our study of PCD was C57BL/6J. This inbred strain is particularly prone to spontaneous craniofacial malformations involving the eyes and other forebrain derivatives as evidenced by

Fig. 2. NBS staining. (A) Three E7 embryos $12 \mathrm{~h}$ after maternal ethanol administration. Note heavy uptake of stain in the ectoderm (arrows) and absence of staining in the endoderm and mesoderm. (B) Control (left) and ethanol-exposed (right) E8 embryos. Note excessive staining in the rhombencephalic neural folds of the latter (arrows). (C) 13-cis retinoic acid (RA)-exposed E8 embryo. Note heavy NBS staining. (D) Control (left) and ethanol-exposed (right) E9 embryos. NBS staining is more intense in the frontonasal prominence, the cranial nerve ganglia, the visceral arch mesenchyme and the somites (dermomyotomes) of the latter. (E) RA-exposed E9 embryo in which excessive NBS uptake is apparent in the dorsal aspect of the first visceral arch. A $1 \mu \mathrm{m}$ section through this region shows large numbers of cell fragments and phagosomes containing cellular debris $(F)$ its high incidence of ocular malformations (microphthalmia which is frequently more severe on the right than the left) (Peirro \& Spiggle, 1967, 1969; Cook \& Sulik, 1986) and a lower incidence of agnathia-holoprosencephaly.

\section{Distribution of Nile Blue Sulphate in control C57BL/6J Embryos}

(1) Embryonic day 7

NBS staining of early-gastrulation-stage embryos (gestational day 7, E7) revealed a surprisingly large number of cells in which the stain was concentrated (Fig. 1C). Observation of whole and dissected embryos at this time illustrated that the stained areas were distributed throughout the developing neural plate. The primitive streak, mesoderm and endoderm appeared unstained.

\section{(2) Embryonic day 8}

On E8, in 3- to 6-somite embryos, staining was localized to the region of the prochordal plate and the portion of the forebrain which is believed to correspond to the optic fields. Bilateral asymmetry of NBS uptake was observed in some specimens. Because Menkes $e t$ al. in their 1970 review note that, in some genetic mutants, the initial teratogenic influence of genetic factors manifests itself by enlargement of normal necrotic areas, it would be particularly interesting to compare the uptake sites in the $\mathrm{C} 57 \mathrm{BL} / 6 \mathrm{~J}$ strain to another that does not have a predisposition for forebrain deficiencies.

By the time the embryos have seven somites, NBS uptake is apparent in the dorsal aspect of the neural folds at the level of the upper hindbrain between the site of emigration of the first and second arch neural crest cells. This staining becomes increasingly intense, spreading to include the area around the periphery of the developing fourth ventricle in 14- to 18-somite embryos (Fig. 1D-F). Staining is also apparent around the distal end of the anterior neuropore, just lateral to the anterior neuropore (nasal placodes?), and in the otic placodes.

\section{(3) Embryonic day 9}

In 20- to 23-somite E9 embryos, staining is present in the region of the olfactory placodes, the trigeminal ganglia, at the periphery of the first closing membrane, in the midline between the cerebral hemispheres and at the lateralmost extent of the neuroepithelium of the 4 th ventricle. By the time the embryo has 24-26 somites (Fig. 2D, left), staining in the ganglia of cranial nerves V, VII-VIII and IX is readily apparent. It is present in the mesenchyme of the visceral arches in positions subjacent to the visceral arch (intermediate and epibranchial) placodes. Other uptake sites include the craniocaudal 
centre of the dermomyotome in the occipital and cervical somites, the region of the olfactory placodes, the choroid fissure and the lens.

\section{(4) Embryonic day 10}

Staining in E10 embryos having 30-35 somites was in similar sites to those on E9, but extended into the thoracic dermomyotomes and became less intense in the craniofacial region.

\section{Ethanol}

Ethanol (alcohol) is an important human teratogen as it is estimated to severely affect $1 \cdot 1$ in 1000 live births and have lesser effects in 3-4 in 1000 children born (Hanson, Jones \& Smith, 1976; Dehaene, SamailleVillette, Samaille, Crepin, Walbaum, Deroubaix \& Blanc-Garin, 1977; Ouelette, Rosett, Rosman \& Weiner, 1977; Olegard, Sabel, Aronsson, Sandin, Johansson, Carlsson, Kylermann, Iversen \& Hrbek, 1979; Sokol, Miller, Debanne, Golden, Collins, Kaplan \& Martier, 1981). Its abuse during pregnancy results in a wide variety of malformations involving many organ systems. The manifestation termed fetal alcohol syndrome (FAS) is diagnosed on the basis of pre- and postnatal growth retardation, characteristic craniofacial anomalies (microcephaly, short palpebral fissures, deficient philtrum, long upper lip and thin upper-vermillion border) and CNS dysfunction. Abnormalities that are not diagnostic of FAS, but are associated with maternal ethanol abuse are termed fetal alcohol effects (FAE) (reviewed by Abel, 1984).

Excellent animal models exist for the range of alcohol-induced malformations seen in the human. They have provided valuable data concerning critical exposure times and clues relative to pathogenesis. When administered acutely at doses within the human tolerance range at gastrulation stages of development to $\mathrm{C} 57 \mathrm{BL} / 6 \mathrm{~J}$ mice, ethanol induces craniofacial malformations characteristic of those in FAS (Fig. 3) (Webster, Walsh, Lipson \& McEwen, 1980; Sulik, Johnston \& Webb, 1981; Sulik \& Johnston, 1982; Webster, Walsh, McEwen \& Lipson, 1983). The malformations include deficiencies in the upper midface and forebrain (Sulik, Lauder \& Dehart, 1984). Ocular malformations including microphthalmia and anterior segment dysgenesis are prevalent and are frequently asymmetrically disposed (Cook et al. 1987). The embryogenesis of these ocular malformations is apparently the same as those that occur spontaneously in this mouse strain. The sequence of changes leading to the definitive malformations have been followed. As early as $12 \mathrm{~h}$ after initial maternal ethanol exposure, forebrain deficiencies, including the territory of the optic fields are apparent. Absence of the normal midline structures results in abnormally close positioning of the olfactory placodes and subsequent deficiency in the medial nasal prominences (MNPs) of the face (Fig. 4). As the MNPs contribute the tip of the nose and the philtrum of the lip, the definitive FAS craniofacial phenotype is, thus, established.

Ethanol exposure during gastrulation results in effects representing a spectrum of severity. The FASlike facies represent the mild end of the spectrum. More severely affected specimens are representative of the holoprosencephaly series of malformations; some specimens presenting with cebocephaly (a nose with a single nostril) and some with complete premaxillary agenesis (absence of all MNP derivatives) (Sulik \& Johnston, 1982) (Fig. 5). Even more severe effects at this treatment time result in virtually complete absence of the forebrain. The associated face essentially consists of two maxillary prominences and a severely deficient mandible (Fig. 6A). Absence of the mandible, which initially is established by mesoderm, suggests a coincidental interference with the anteriormost early mesoderm. Agnathia-holoprosencephaly
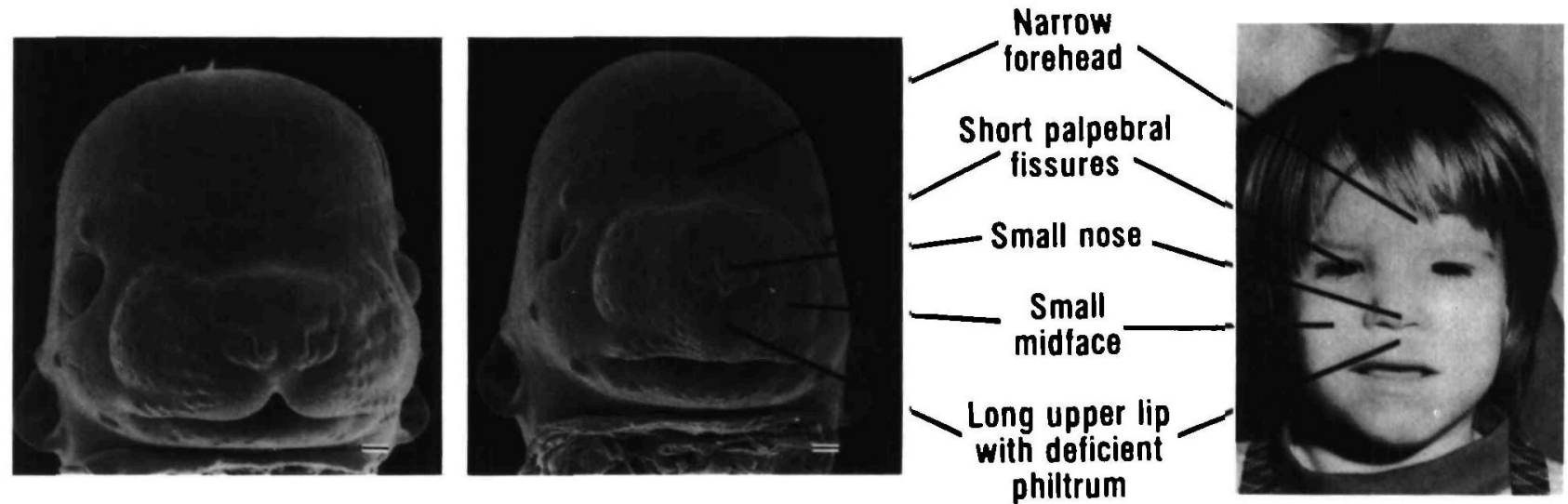

Fig. 3. Craniofacial features in a mouse model for fetal alcohol syndrome and in an affected child. Notable features in the E14 fetus as compared to the control include microcephaly, small palpebral fissures, small nose and long upper lipfeatures also seen in the child. Bar, $20 \mu \mathrm{m}$ [Child's photograph courtesy of Dr S. Clarren]. 

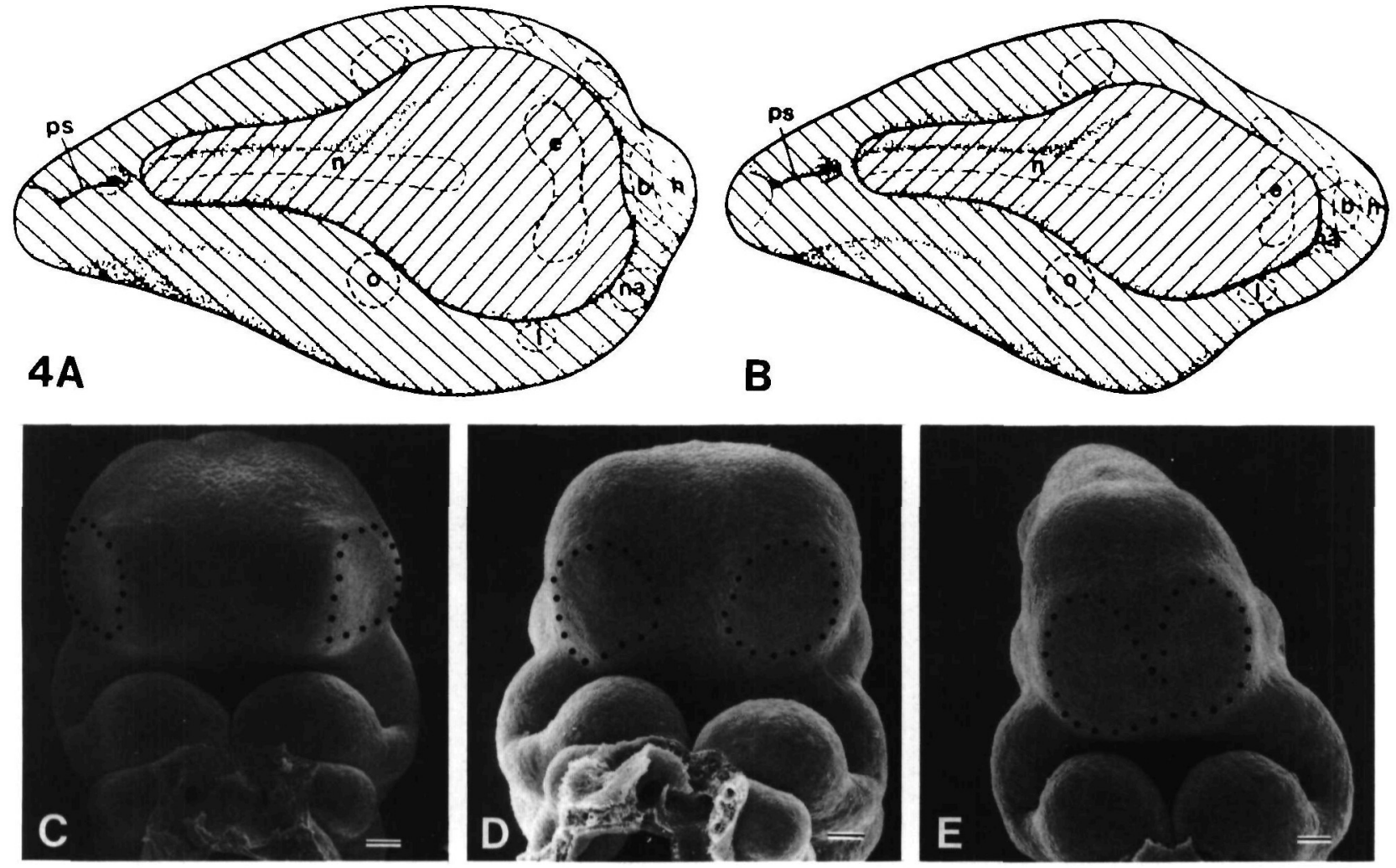

Fig. 4. Comparison of diagrams (A) and (B) illustrates narrowing of the forebrain which reduces the eye fields and brings the nasal placodes too close together as occurs following ethanol exposure during gastrulation stages (E7). By E10, the position of the nasal placodes (circled) is evident in scanning electron micrographs. Spacing of the placodes is reduced to varying degrees in affected $(D, E)$ as compared to control $(C)$ embryos. $b$, buccopharyngeal membrane; e, eye field; h, heart; 1 , lens placode; n, notochord; na, nasal placode; O, otic placode; ps, primitive streak. Bar, $10 \mu \mathrm{m}$ [Modified from Sulik, 1984].

(otocephaly) studied in a mutant mouse strain appeared to involve mesodermal cell death (Juriloff, Sulik, Roderick \& Hogan, 1985). As the maxillary mesenchyme is neural crest derived and the region of the brain from which these cells originate (mesencephalon) is present, maxillary prominences still form.

Cyclopia is only occasionally observed following treatment at this time. Presumably, it results from a slightly later exposure time than the other malformations commonly included in the holoprosencephaly spectrum. Major deficiencies in midline structures following the time when the optic fields are closely associated with the midline would result in preservation of enough of the optic primordia to form the conjoined eye fields typical of cyclopia (Fig. 6B). Exencephaly, failure of the cranial neural folds to fuse, also commonly results from ethanol exposure on E7 and E8 (Fig. 6C). With the exception of neural tube defects, these severe malformations are not typically seen in the offspring of alcoholic women. They are frequently reported as occurring spontaneously or are associated with chromosomal aneuploidy (Cohen, 1982).
Ethanol treatment $1 \frac{1}{2}$ days later in the mouse, when the embryos have approximately $7-10$ somites (at the time of neural crest cell emigration), results in very different craniofacial malformations as well as cardiovascular and thymic abnormalities (Webster, Germain, Lipson \& Walsh, 1984; Daft, Johnston \& Sulik, 1986; Sulik, Johnston, Daft \& Russell, 1986; Webster, 1988). This pattern of malformation is consistent with that of the DiGeorge sequence. The facies are characterized by micrognathia, apparently low-set ears with abnormal pinnae, a short philtrum, midline clefts in the nose, cleft palate and ocular hypertelorism. This phenotype overlaps with that of the velocardiofacial (Shprintzen) syndrome (Shprintzen, Goldberg, Lewin, Sidote, Berkman, Argamaso \& Young, 1978). The DiGeorge sequence has been described in the offspring of alcoholic mothers (Ammann, Wara, Cowan, Barrett \& Stechm, 1982).

Relatively few publications have addressed the question of ethanol's teratogenic mechanism of action (reviewed by Abel, 1984; Webster, 1988). Among the cellular effects considered are increased peroxidase activity (Dreosti, 1984) interference with cytoskeletal components (Hassler \& Moran, 1986), 

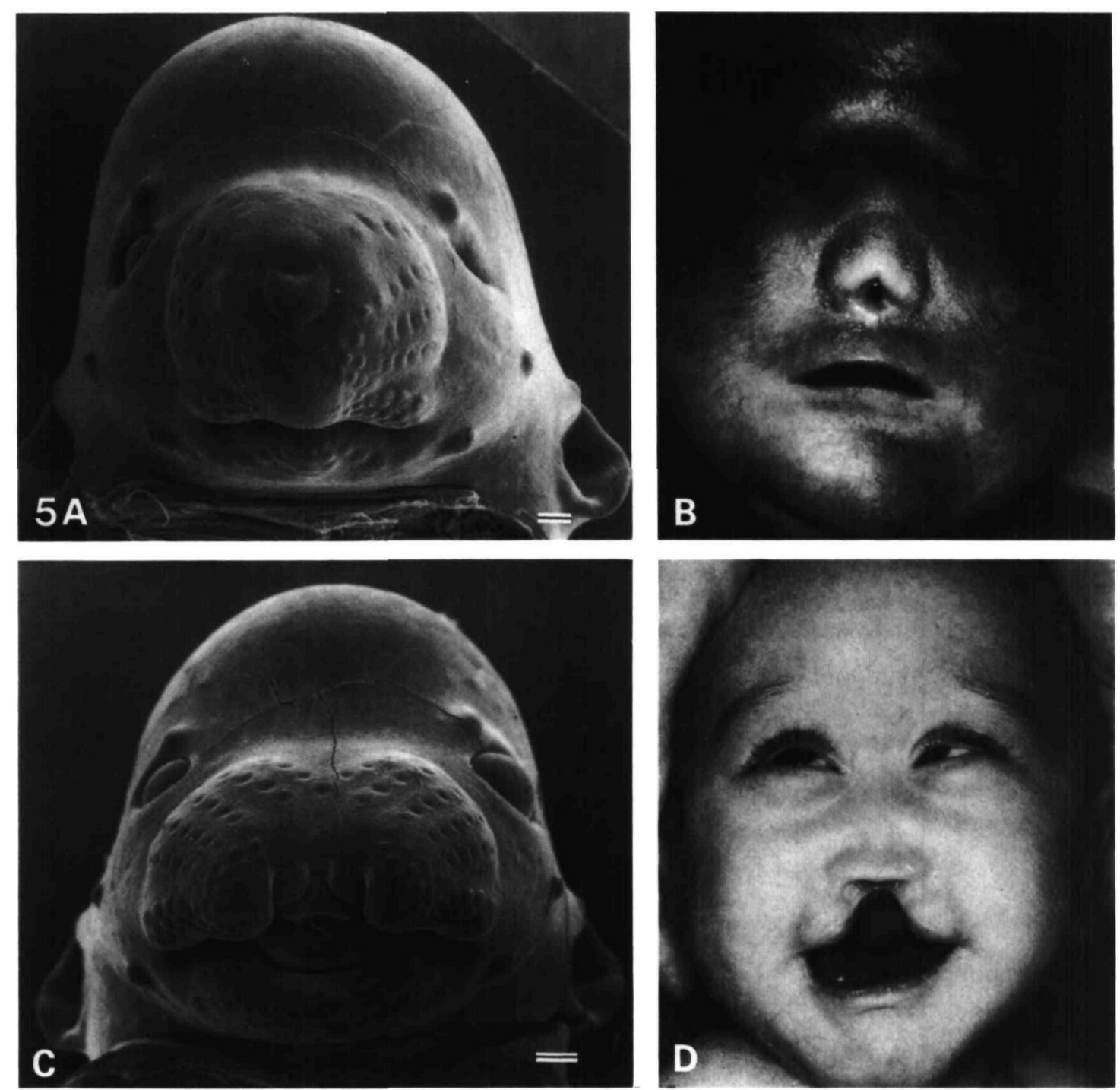

Fig. 5. Cebocephaly, a member of the holoprosencephaly series of malformations is characterized by at nose having a single nostril as in an ethanol-affected E14 mouse fetus (A) and in a child (B). Complete premaxillary agenesis (absence of medial nasal prominence derivatives) also is in the holoprosencephaly series, presenting in an E14 mouse (C) and in the human (D) as a median 'cleft' lip. Bar, $20 \mu \mathrm{m}$ [(B), courtesy of Dr M. M. Cohen, (D) from Ross \& Johnston, 1972 .

diminished DNA synthesis and suppressed rates of cell division (Dreosti, Ballard, Belling, Record, Manuel, \& Hetzel, 1981; Webster, 1988) and direct effects on membranes resulting in excessive fluidity (Daniel \& Evans, 1982). Studies showing interference with cell migration (Nakatsuji, 1983; Nakatsuji \& Johnson, 1984; Hassler \& Moran, 1986) and subsequent effects on gastrulation and neural crest populations suggest inhibition of morphogenetic movements as a significant teratogenic effect of ethanol.

Sandor's early studies (1968) of ethanol-exposed chick embryos illustrated necrosis induced by this teratogen. The most marked changes were seen in the CNS. Similarly, Bannigan and coworkers (Bannigan \& Burke, 1982; Bannigan \& Cottell, 1984) noted that within $6 \mathrm{~h}$ following ethanol treatment of E9 mouse embryos, many degenerating cells and necrotic debris could be seen in the neuroepithelium of the neural groove and neural tube. Webster \& Schembri (Web ster, 1988) noted that cell death in E9 embryos was not localized in any one part of the embryo and, in addition to its presence in the neural tube, was found in the somites and in the mesenchyme surrounding the gut. Histological sections of mouse embryos exposed to ethanol at $8 \frac{1}{2}$ gestational days showed marked pyknosis in the cranial mesenchyme $12 \mathrm{~h}$ after treatment (Sulik et al. 1986). These authors also noted large numbers of degenerating cells in the neuroepithelium, the otic and epibranchial placodes and closing membranes. 

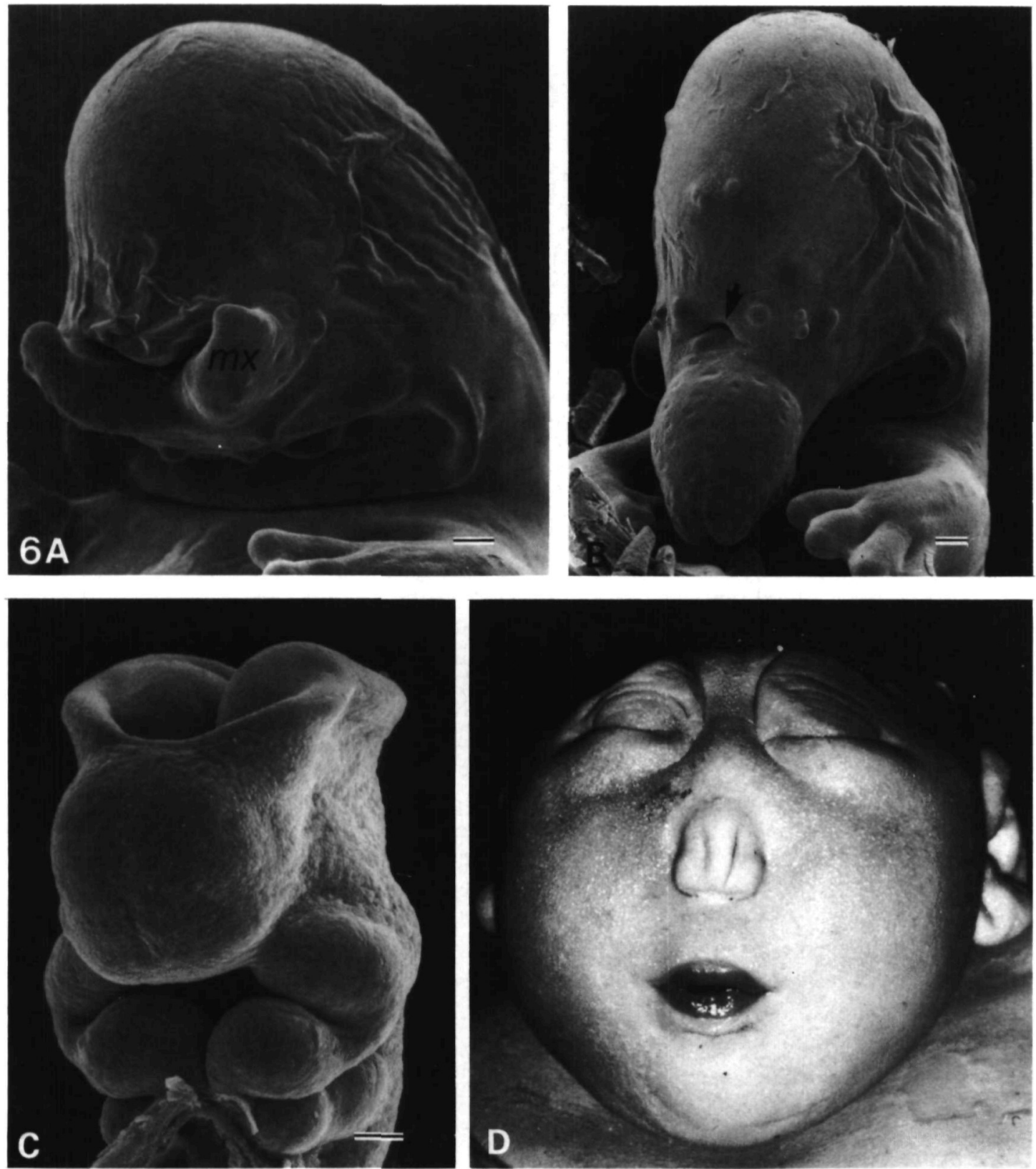

Fig. 6. Severe craniofacial malformations which occassionally result from ethanol exposure on E7 in mice include absence of the forebrain, mandible and frontonasal prominence derivatives. The remaining facial structures are neuralcrest-derived maxillary prominences $(m x)(\mathrm{A})$. A centrally positioned, small eye (arrow) and a snout consisting only of maxillary prominence-derived tissue is illustrated in $\mathbf{B}$. Incomplete closure of the cranial neural tube, in addition to abnormally close positioning of the olfactory placodes as in the E10 mouse embryo in C would be expected to result in anencephaly and the abnormal facial appearance as in the child in D. (Child's photograph courtesy of Dr M. M. Cohen, Jr.) Bar, $20 \mu \mathrm{m}$.

Recent investigations using NBS to stain whole mouse embryos exposed to ethanol at times ranging from E7 to E9 have clearly illustrated excessive cell death within $12 \mathrm{~h}$ following maternal treatment. The sites of cell death correspond to those of normal PCD but the areas are expanded and stain with greater intensity than in the controls (Fig. 2A,B,D). Some areas of PCD appear prematurely as readily apparent in the caudal somites of affected embryos. We propose that the differing patterns of malformation which can be induced by ethanol at different exposure times is largely based on the changing pattern of PCD. The basis for this excessive cell death remains to be elucidated. One possibility is that lipid peroxide formation resulting from ethanol exposure (Dreosti, 1984) leads to rupture of lysosomal membranes and 
release of hydrolytic enzymes (Wills \& Wilkinson, 1966).

\section{Retinoic acld}

Alterations in levels of retinol (vitamin A) and other retinoids have long been used in experimental teratology (reviewed by Geelen, 1979), and have been found effective in inducing experimental craniofacial malformations (Hale, 1933; Cohlan, 1953; Kalter, 1960; Walker \& Crain, 1960; Kochhar \& Johnson, 1965; Poswillo, 1974; Yip, Kokich \& Shepard, 1980; Wiley, Cauwenbergs \& Taylor, 1983; Kay, 1987). Renewed interest in retinoid teratogenicity has followed the introduction of 13-cis retinoic acid (13-cis RA, isotretinoin, Accutane ${ }^{\circledR}$ ) as an effective treatment for severe cystic acne, subsequent inadvertant exposures during pregnancy and a resultant spectrum of malformations termed retinoic acid embryopathy (RAE) in the offspring (Lammer et al. 1985; Rosa, Wilk \& Kelsey, 1986). Craniofacial features include abnormal external and middle ears (microtia or anotia), mandibular and midfacial underdevelopment, wide clefts of the secondary palate and brain abnormalities, many involving the hindbrain (Fig. 7A). Among several of the affected children, the pattern of malformation has been consistent with that of the DiGeorge Sequences. As for alcohol, excellent animal models exist (Webster, Johnston, Lammer \& Sulik, 1986; Willhite, Hill \& Irving, 1986). Retinoic acid, as opposed to retinol, is rapidly cleared from the maternal system, therefore, allowing analysis of affects on narrow time periods in development.

Shenefelt (1972), using all-trans-RA conducted an extensive teratology study on hamster embryos and illustrated critical periods for a wide variety of malformations. Webster et al. (1986) showed that gestational-age-dependent effects could be induced by 13-cis RA following single maternal doses of $200 \mathrm{mg} \mathrm{kg}^{-1}$ at times ranging from E7t to E9. The earlier treatment times resulted in a high incidence of embryo lethality and open cranial neural tubes. The later treatment times resulted in thymic and great vessel abnormalities. External ear malformations could be induced at all the time periods examined. More recent investigations in our laboratories have shown that lower doses $\left(50 \mathrm{mg} \mathrm{kg}^{-1}\right)$ given acutely early on E7 result in the same types of malformations as observed with ethanol exposure at this time (C. S. Cook and K. K. Sulik, unpublished observation).

Gestational-day-8 exposure was shown, following SEM analyses, to result in deficiencies in the visceral arches. Treatment at E $8 \frac{1}{4}$ had a particularly marked effect on the second arch (Fig. 7B,C). At the time of treatment, embryos had approximately 3-5 somites; the stage when neural crest cells just begin to migrate into the first arch area and have not yet begun to enter the second arch. Absence of the second arch was associated with abnormal (rostral) placement of the otocyst. This positioning had previously been noted by Morriss (1976) \& Poswillo (1974). Scanning electron microscopy (SEM) of 8-somite embryos $(12 \mathrm{~h}$ after 13-cis RA exposure) from which the surface ectoderm was removed revealed blebbing in the neural crest cells which had left the midbrain neural folds. There was an apparent absence of neural crest cell migration at more caudal levels (Fig. 7D-F). NBS staining illustrated excessive uptake which was particularly notable at the crest of the rhombencephalic neural folds (Fig. 2C). We propose that excessive cell death in this region irreversibly diminishes the number of neural crest cells that should populate the arches. In addition, loss of the dorsal neuroepithelial cells in the upper hindbrain would presumably result in cerebellar abnormalities. A consequence of neuroepithelial loss may also be abnormal positioning of the otocyst. Thus, external ear, mandibular and cerebellar abnormalities as seen in RAE may be explicable on the basis of excessive cell death in the rhombencephalic neural folds prior to the time of neural crest cell emigration into the first and second arches. Similar effects on neural crest cells destined to populate the third and fourth arches would be expected to result in thymic and great vessel abnormalities (Kirby, Gale \& Stewart, 1983; Bockman \& Kirby, 1984; Thayer, Adams, Effmann \& Sulik, 1987).

Axial skeletal malformations noted in this animal model following treatment on E8 probably result from the excessive cell death which is present around the posterior neuropore (Fig. 2C) or from a concurrent effect on the gastrulation process which is still occurring in the caudal part of the embryo (Morriss, 1973).

Treatment on E9 (a time after neural crest cells should be in place in the frontonasal prominence and visceral arches) resulted in craniofacial malformations comparable to those that characterize mandibulofacial dysostosis (Fig. 8) (Sulik, Johnston, Smiley, Speight \& Jarvis, 1987). The external ear malformations and deficiencies in the dorsal aspects of the maxillary and mandibular regions characteristic of this syndrome appear to be related to excessive cell death in the proximal aspect of the first and second visceral arches. The region of cell death observed is subjacent to the trigeminal placode and the epibranchial placode of the second arch (Fig. 2E,F). The cell populations involved in the subsequent malformation undoubtedly include placode-derived cells (primarily?) as well as cells of neural crest and/or mesodermal origin (secondarily?). Tissues of neural crest origin including the skeletal components of the ramus 
Teratogens, malformations and cell death
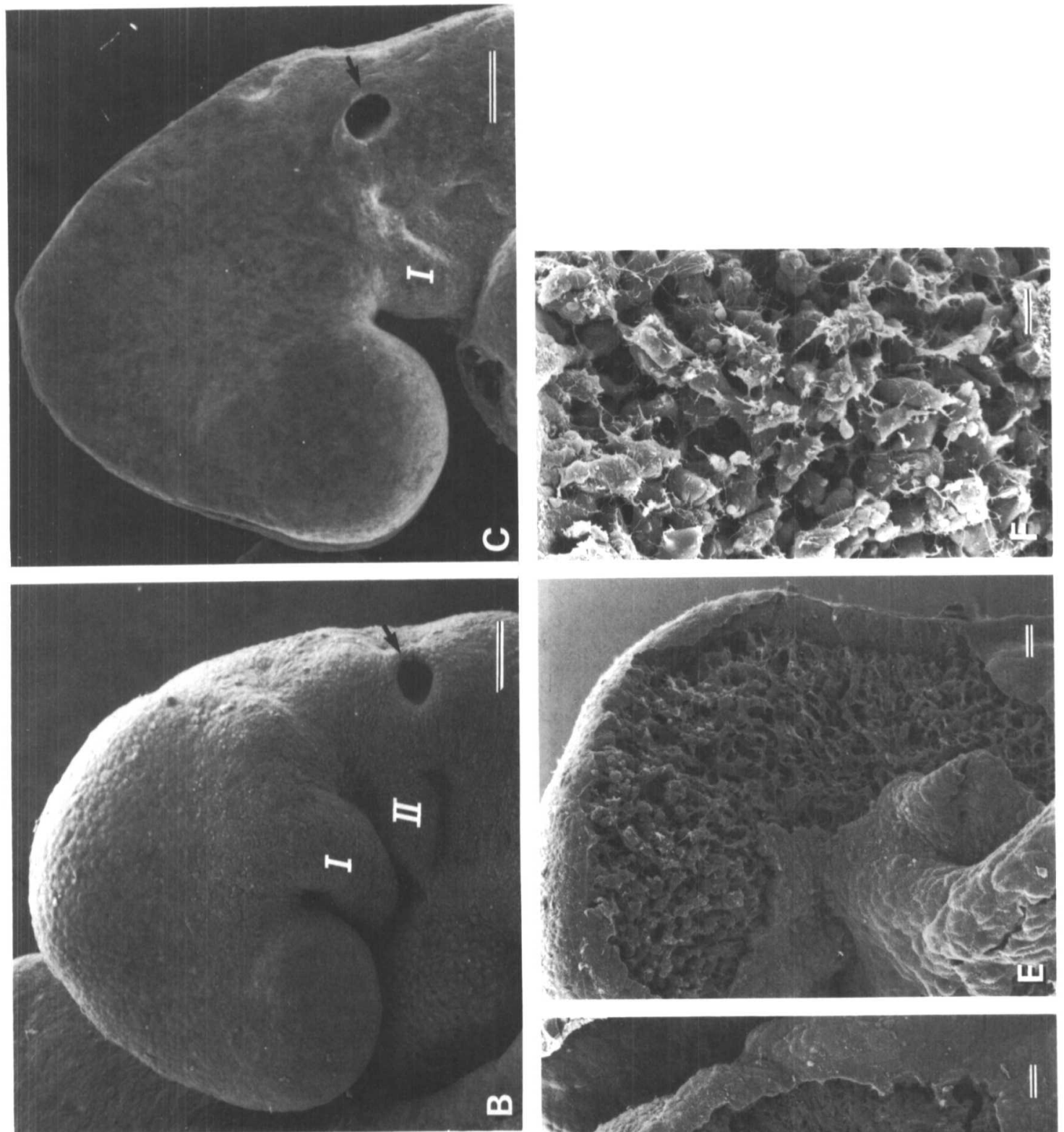

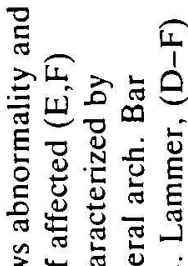

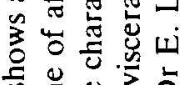

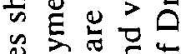

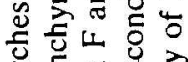

可. 政

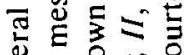

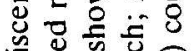

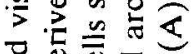

它这

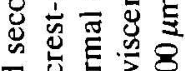

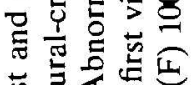

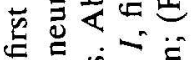

象它

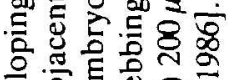

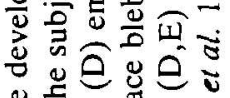

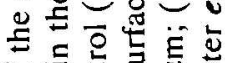

廿.

अ

范

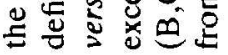

$\infty$

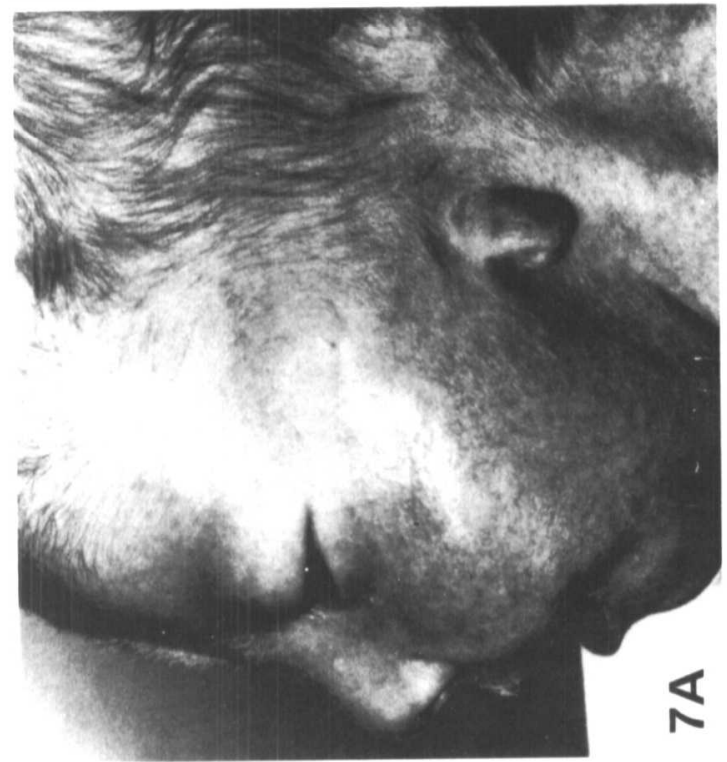

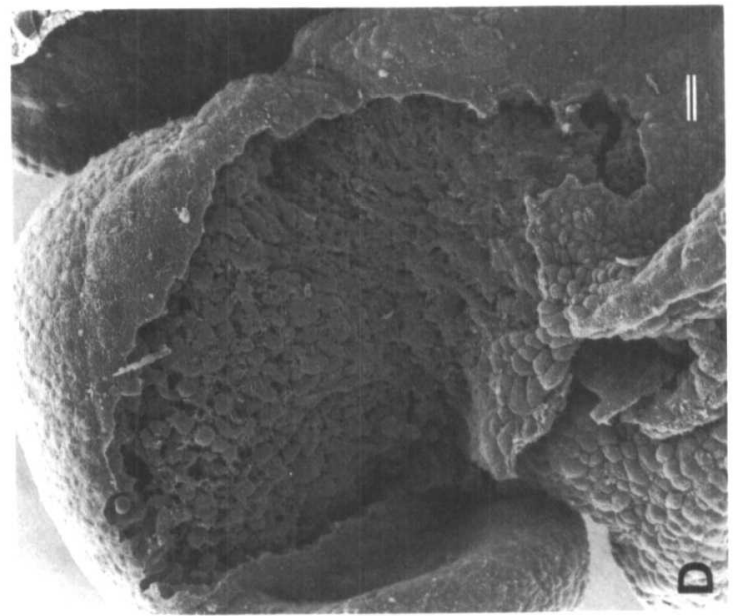

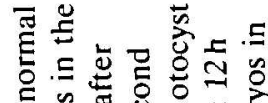

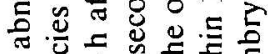

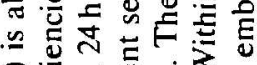

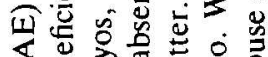

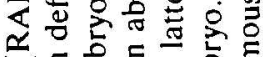

.

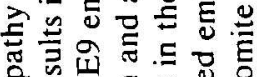

응

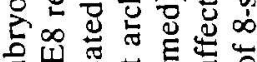

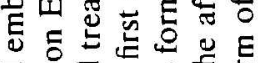

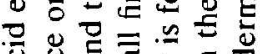

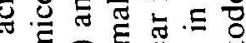

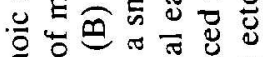

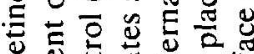

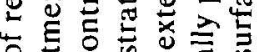

क्ष

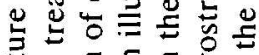

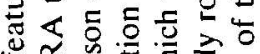

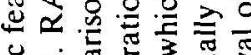

它定总

¿.

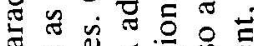

帘

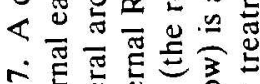

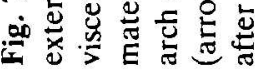



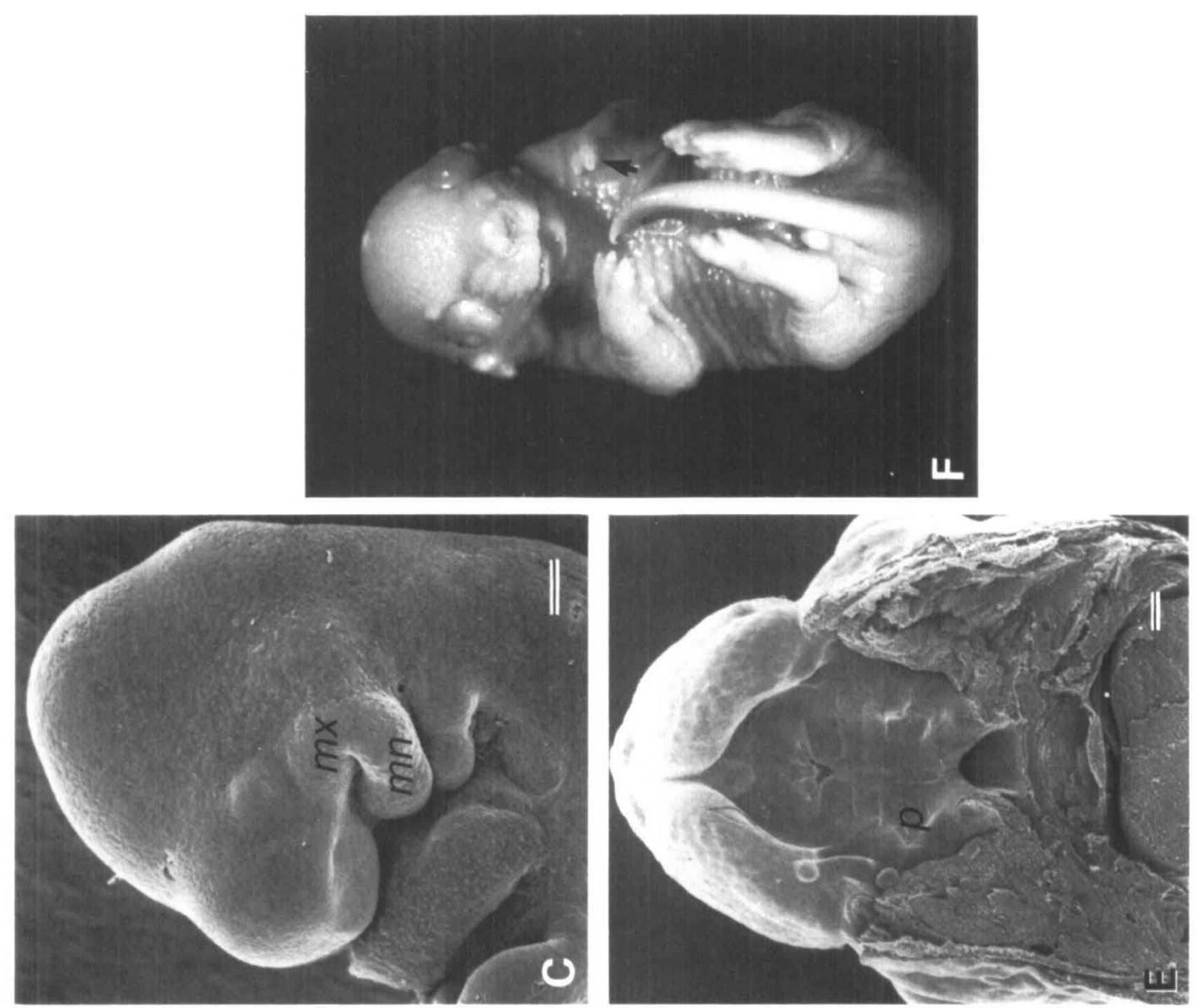

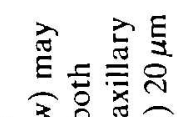

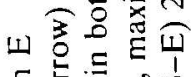

5 究

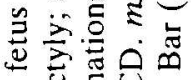

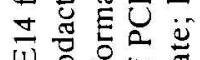

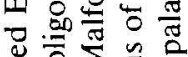

可远

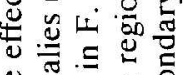

运.

o 要专

ป ᄃ

可记

之ंगे

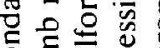

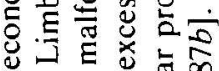

क

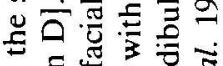

$\Xi \Xi$ 远

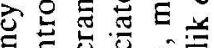

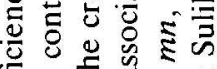

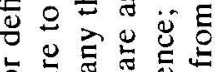

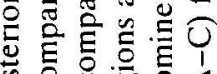

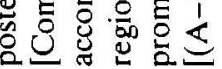
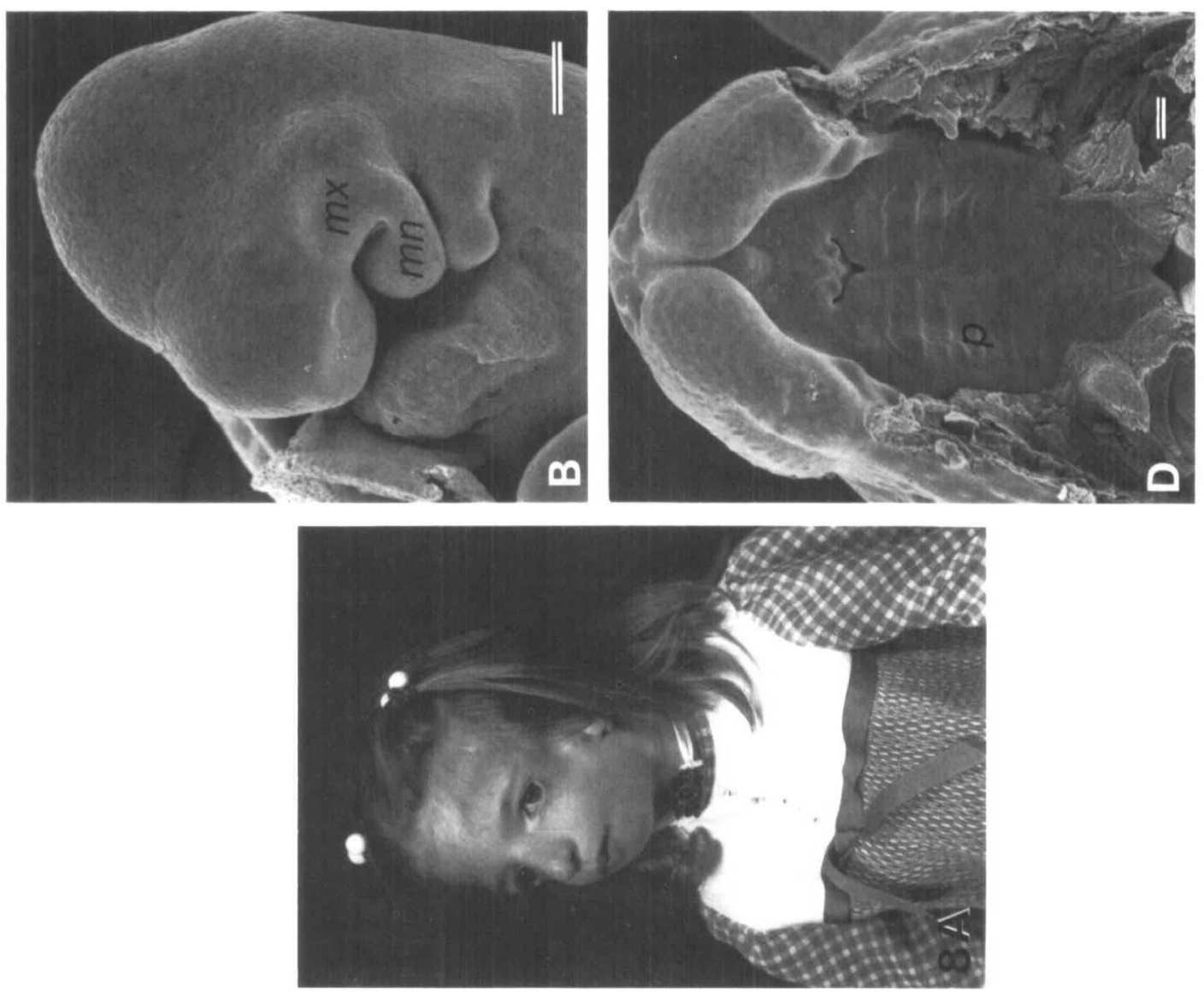

$\frac{n}{2}$

$\varangle$

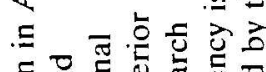

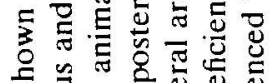

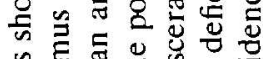

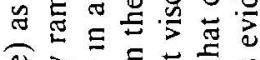

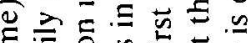

它월

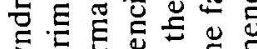

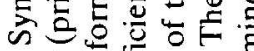

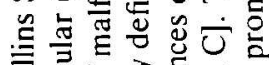

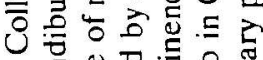

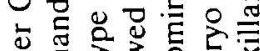

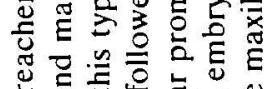

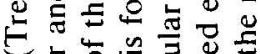

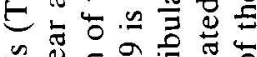

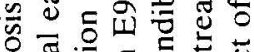

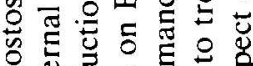

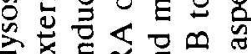

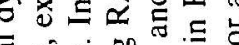

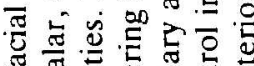

흘 흘

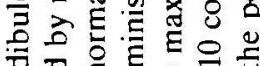

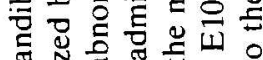

$\sum$ 类

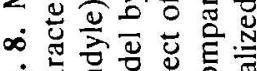

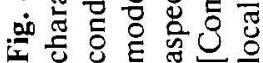


and condyle of the mandible as well as the zygomatic region were deficient.

Wide clefts of the secondary palate were occasionally observed in this animal model, but more frequently noted were clefts involving only the posterior aspect of the palate (Fig. 8D,E) (Smiley, Speight, Johnston \& Sulik, 1987). The human counterpart would be deficiencies in the soft palate or, in more severe cases, clefts involving the soft palate and the posterior aspect of the hard palate. This palatal morphology is typical of mandibulofacial dysostosis as well as syndromes having this facial phenotype as well as limb reduction defects (postaxial oligodactyly = Miller's syndrome; preaxial oligodactyly = Nager's syndrome). 13-cis RA treatment on E9⿺辶丶 in the mouse induced reduction-type limb malformations (Fig. 8F) (Sulik, Johnston \& Dehart, 1987). Excessive cell death in the limb bud apical ectodermal ridge appeared to be involved in the pathogenesis. The distribution of excessive cell death in regions of PCD provides a basis for understanding the composition of syndromes in which malformations appear to be unrelated by tissue type or location (Sulik, Webster, Johnston \& Cook, 1987).

Schweichel (1971) showed that vitamin A 'expanded and strengthened' interdigital necrotic zones in the rat and suggested that this resulted from the labilization of lysosomes due to its detergent action on membranes (Dingle, 1961; Fell \& Dingle, 1963). Lysosomal enzymes were believed to be released into the cytoplasm of the cells of origin as well as into the intercellular spaces, resulting in cell death. Schweichel \& Merker (1973) described vitamin Ainduced necrosis as being consistent with their type-2 cell death.

Marks, Pearse, Hashimoto \& Barton (1983) note that after retinoid treatment, lysosomal membranes of all cells do not lyse and suggest that only those membranes at a particular stage of differentiation or which have been perturbed in some other way react. Further analysis of the effects of the retinoids on lysosomes, the possible roles of retinoid binding proteins (Sporn, Roberts \& Goodman, 1984; Dencker, d'Argy, Danielsson, Ghantous \& Sperber, $1987)$ and effects related to gene expression are needed.

Membrane destabilization by the retinoids would be expected to interfere with many cellular functions. Blebbing of plasma membranes was noted previously by Morriss (1973) in gastrulating mesoderm cells and by Thorogood, Smith, Nicol, McGinty \& Garrod (1982) and Webster et al. (1986) in neural crest cells following retinoid exposure. This might be expected to interfere with the migratory ability of these cell types. However, as shown by Thorogood et al. (1982), recovery follows removal of the retinoid in vitro. In vivo, recovery from a brief interference with cell migration might also be expected but sufficient recovery probably does not follow the excessive cell death of progenitor cells.

\section{Hyperthermla}

Hyperthermia is teratogenic in many species of animals (reviewed by Edwards, 1986). It is particularly damaging to the developing CNS and, depending on the species and stage of exposure, it induces exencephaly, holoprosencephaly, encephalococle, neuronal heterotopias, micrencephaly, microphthalmia, neurogenic talipes or arthrogryposis. Facial malformations include micrognathia, midfacial hypoplasia, external ear anomalies and cleft lip and/or cleft palate. Other organ systems are also affected by sufficient maternal temperature elevations. CNS and facial abnormalities have been associated with human maternal hyperthermia at 4-14 weeks of gestation (facial dysmorphogenesis is prevalent following exposure at 4-7 weeks) (Pleet, Graham \& Smith, 1981). In the rat, typical craniofacial features following hyperthermic stress on E9 consisted of absence of the eyes and other forebrain derivatives, encephaloceles, reduced midface development, and in some embryos no frontonasal prominence derivatives (Webster, Germain \& Edwards, 1985).

Germain, Webster \& Edwards (1985) illustrated in a rodent model that duration of temperature elevation as well as the extent of the elevation are important. Low, sustained temperature elevations appear to be as damaging as repeated spikes of higher elevation. The amount of time between temperature spikes is also a significant factor with a $6-8 \mathrm{~h}$ interval in mice being particularly damaging (Webster \& Edwards, 1984). Elevations of $1 \cdot 5-2 \cdot 5^{\circ} \mathrm{C}$ above normal body temperatures represent the threshold for teratogenesis in a number of species. In the human, febrile episodes, excessive exercise, the use of hot baths and saunas can result in such elevations.

Cell death is a major factor in heat-induced CNS teratogenesis. Edwards (1986) states that mitotic cells are most susceptible. A pulse of hyperthermic stress also retards mitotic activity for about $4 \mathrm{~h}$, resulting in partial mitotic synchrony. This may explain the abnormally large proportion of cells that die after a second pulse. The pathogenesis of heat-induced malformations in areas other than the CNS have not been well studied. Microvascular changes in the placenta and/or embryo (which could be secondary to cell death) have been noted. Possible relationships of hyperthermia-induced cell death to patterns of PCD have not been examined. We would suspect that some correlation would exist. Von Ardenne \& Krüger (1979) suggest that hyperthermia results in intra and 
extracellular leakage of lysosomal enzymes as does vitamin A. However, the major insult to the CNS is probably related to other factors, as well.

Protection against heat-induced cell death by prior exposure to a mild dose of heat has been shown to be associated with the production of heat shock proteins (German, 1984; Walsh, Klein, Hightower \& Edwards, 1985; Mirkes, 1985). The functions of heat shock or stress proteins, which can also be induced by other agents including hypoxia and ethanol, in cell protection remain unknown.

\section{lonizing radiation}

Radiation-induced teratogenesis has received considerable research attention in the human (reviewed by Brent, 1980) and in experimental animals (reviewed by Hicks \& d'Amato, 1966). In the human, growth retardation and CNS effects such as microcephaly or eye malformations are the cardinal manifestations of the effects of intrauterine ionizing radiation. Because ionizing radiation acts as a direct insult to the embryo, extrapolation from animal models to the human is readily made. Most of the systematic studies of the effects of radiation on development have utilized rats and mice for which a common range of exposure has been between 100 and 400 rads. The CNS and eye, which appear to be particularly sensitive to radiation effects, may be affected by doses of $5-10$ rads.

Hicks \& D'Amato (1966) have reviewed the types of malformations that result from acute exposure of pregnant rats or mice to $100-200$ rads on various gestational days. Similar malformations result from radiation of gastrulating and neurulating embryos as noted following exposure to ethanol, retinoic acid or hyperthermia, i.e. exencephaly and microphthalmia. Malformations consistent with those in the holoprosencephaly spectrum were observed by Russell (1950) and by Murakami, Kameyama, Majima \& Sakurai (1961). Russell \& Russell (1954) also noted a wide range of stage-dependent radiation-induced malformations involving organ systems other than the CNS.

The cellular mechanisms of radiation-induced teratogenesis are only understood in part. They range from sublethal injuries affecting differentiation and cellular interactions to effects on rates of proliferation and cell death (Hicks \& D'Amato, 1966). Response of cells to radiation is dependent upon the cell cycle with $\mathrm{G} 2$ being a particularly radiosensitive stage. Cell death is linked, in some cases, to chromosomal damage which is expressed during mitosis. Injury to DNA is a characteristic result of radiation.

Bacq \& Alexander (1961) proposed that radiationinduced cell death involves altered permeability of intracellular structures and enzyme release; i.e. cellular lysis by lysosomal enzymes. Subsequent studies (Wills \& Wilkinson, 1966; Trocha \& Catravas, 1980) have, indeed, shown that irradiation results in the rupture of lysosomal membranes and suggest that this results from lipid peroxide formation. It is of interest that Hicks \& D'Amato (1966) made note of excessive cell death in the dermatome cells of E12 rat tail somites as this is a region of PCD. This excessive necrosis was observed less than one hour after teratogen exposure. These authors also noted that other sensitive regions including the dense mesenchyme of the facial prominences showed extensive necrosis, paralleling the nervous system in time of response with cell destruction becoming evident at about $6 \mathrm{~h}$ and being maximal by $12 \mathrm{~h}$ postradiation. Further studies examining a possible association between the areas affected by ionizing radiation and regions of PCD are needed.

\section{Hypoxia}

Hypoxia has been extensively studied in experimental animals and is capable of inducing a wide variety of malformations in virtually all organ systems (reviewed by Grabowski, 1970). Oxygen deficiency has been induced by use of partial vacuums, air diluted with nitrogen, use of respiratory enzyme inhibitors, maternal anaemia, vascular clamping and a variety of other means. Hypoxia in the human embryo may result from cigarette smoking, reduced atmospheric oxygen levels as occur at high elevations, as well as placental insufficiency.

Of particular interest for this review is hypoxiainduced cleft lip. Maternal respiratory hypoxia (10\% $\mathrm{O}_{2}$ ) increases the incidence of cleft lip in $\mathrm{CL} / \mathrm{Fr}$ mice from the spontaneous level of $36 \%$ to $89 \%$ (Millicovsky \& Johnston, 1981). Previous studies of teratogen-induced and spontaneous cleft lip have emphasized size reduction and abnormal positioning of the facial prominences as possible pathogenetic mechanisms (Trasler, 1968; Sulik, Johnston, Ambrose \& Dorgan, 1979; Trasler \& Leong, 1982). The idea that degeneration of the olfactory placode may be involved in the genesis of cleft lip has recently been advanced by Bronsky, Johnston \& Sulik (1986). Pathogenesis studies conducted on Ell mouse embryos following $24 \mathrm{~h}$ of maternal hypoxia showed the presence of cellular debris resulting from cell death in the deepest aspects of the invaginating nasal placodes (Fig. 9). This, as well as overall growth retardation of the facial prominences, leads to inability of the facial prominences to contact and fuse. Grabowski (1970) states that malformations in embryos exposed to acute hypoxia are due largely to the direct effects of 

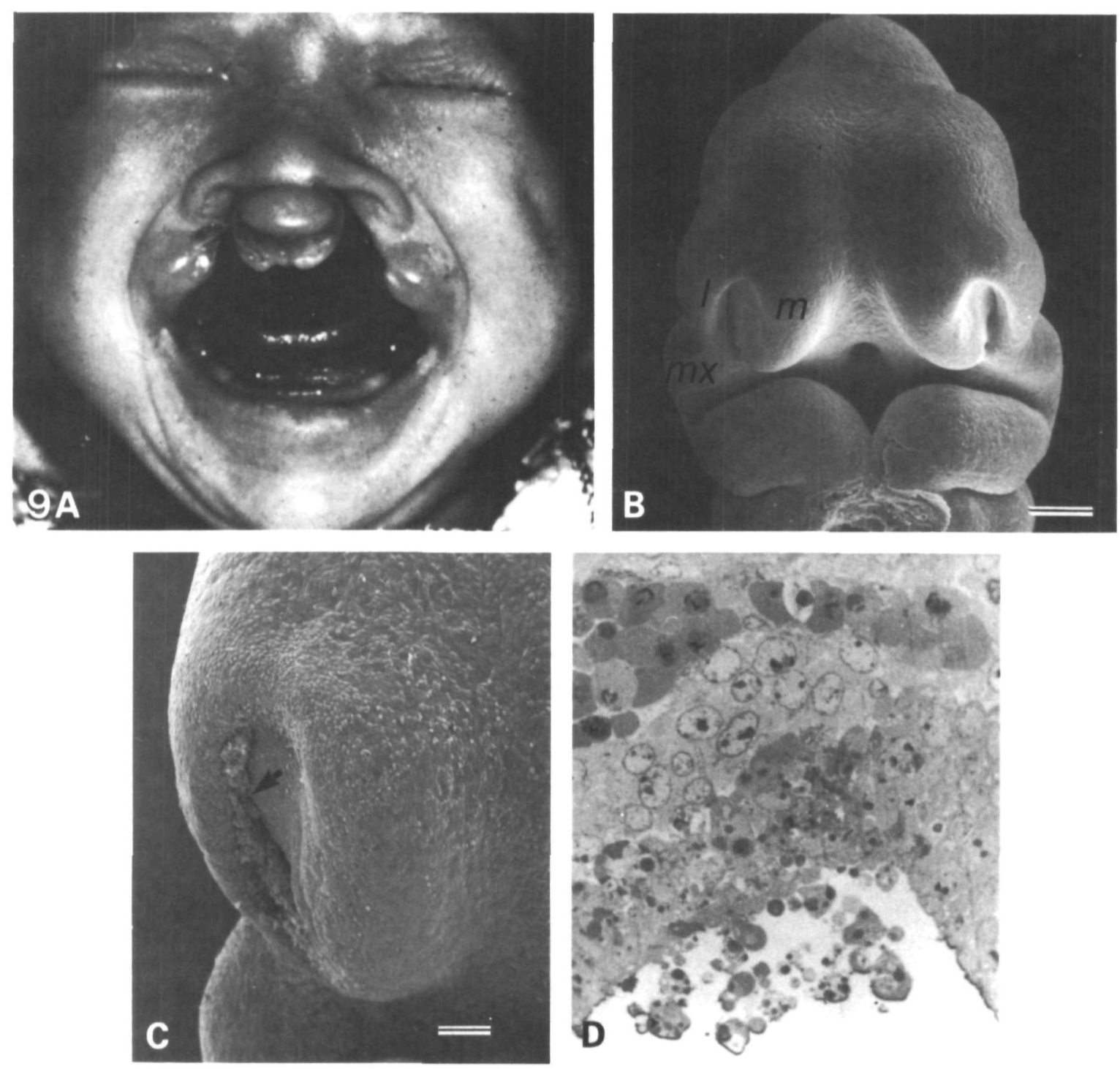

Fig. 9. Cleft lip, either bilateral as in A or unilateral, is a commonly occurring craniofacial malformation which results from nonunion of the maxillary and lateral nasal prominences with the medial nasal prominences. [See E11 mouse embryo in B.] Hypoxia-induced cleft lip in the mouse is associated with cell death and resultant accumulation of cellular debris (arrow) in the deepest aspect of the invaginating olfactory placodes (C,D). $m x$, maxillary prominence; $l$, lateral nasal prominence; $m$, medial nasal prominence, Bar (B), $20 \mu \mathrm{m}$, (C) $10 \mu \mathrm{m}$ [(A) from Ross \& Johnston, 1972; (B) from Sulik \& Johnston, 1982, (C,D) from Bronsky et al. 1987].

oxygen deficiency on the cells of affected organs, resulting in extensive necrosis.

PCD has been noted in the olfactory placodes of E8-10 mouse embryos. It is particularly prevalent in the midline of the placodes (the future site of greatest curvature; the deepest part of the olfactory pit) at the later stages. Von Ardenne \& Krüger (1979) have suggested that oxygen deficiency leads to glycolysis followed by acidification of intercapillary spaces and subsequent necrosis resulting from intra- and extracellular leakage of lysosomal enzymes.

It is also interesting to speculate that oxygen deficiency directly interferes with energy-requiring morphogenetic movements such as invagination of the olfactory placodes (Smuts, 1981). It is noteworthy that chemicals which interfere with oxidative enzymes such as 6-aminonicotinomide, boric acid and phenytoin effectively induce cleft lip in mice. Exogenous energy sources such as glycerophosphate, succinate and ascorbate have been shown to act as antiteratogens to agents such as 6-AN (Landaur \& Sopher, 1970). Further studies of hypoxia-induced cleft lip, preferably involving short periods of hypoxia, are needed to clarify the relationship between the pathogenetic phenomena and the subsequent malformation. In addition, analyses of the effects of hypoxia at other exposure times and relationships to areas of PCD are needed. 

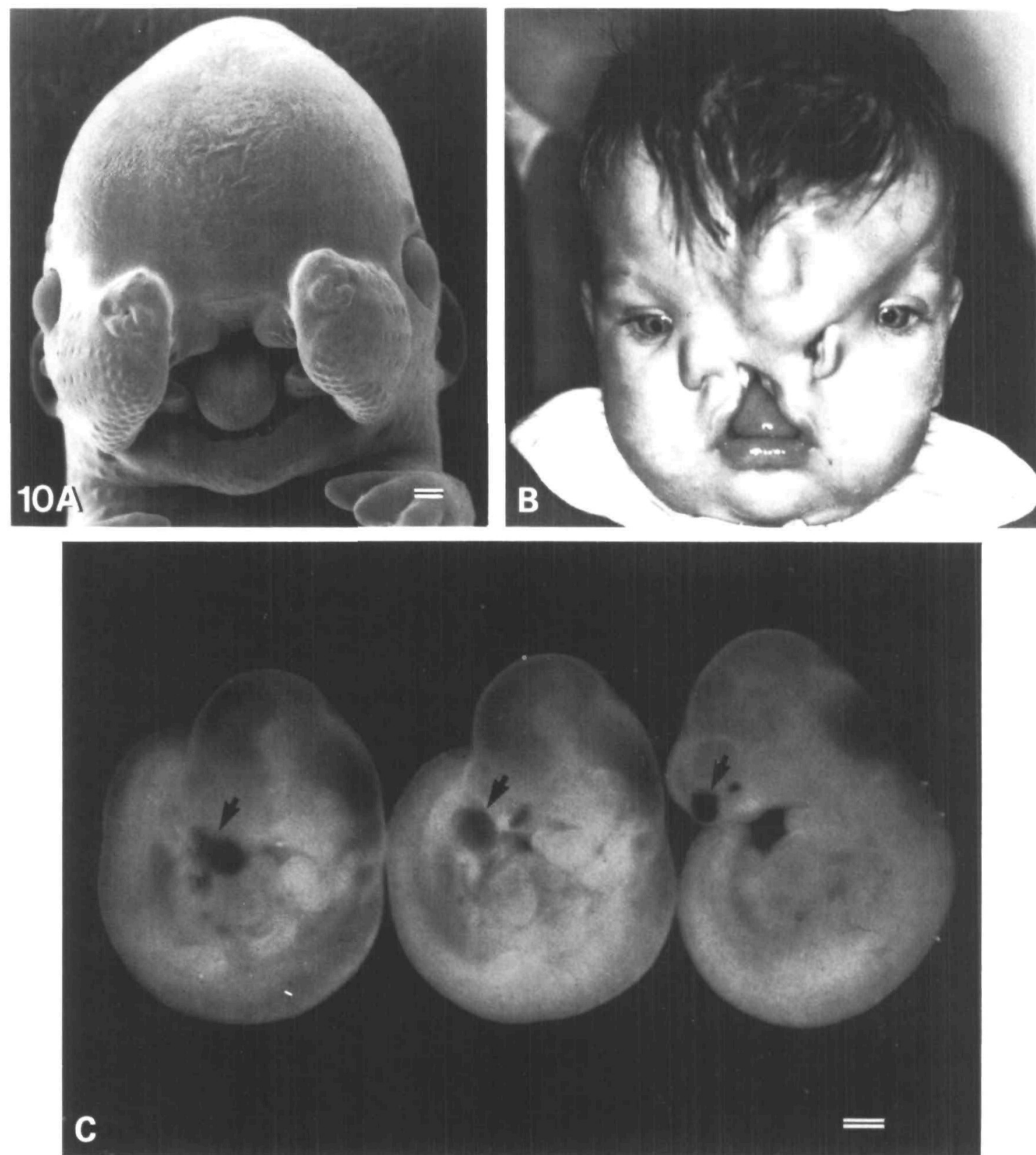

Fig. 10. Frontonasal dysplasia (median facial cleft) as seen in an animal model (A) and in a child (B) may result. in part. from distension of the neural tube and vasculature. This follows teratogenic insult with methotrexate on $E 9$ in the mouse. Note large vascular blebs (arrows) located close to the nasal placodes of E10 affected embryos. Bar (A,C), $20 \mu \mathrm{m}[(\mathrm{B})$ courtesy of Dr DeMyer, (A,C) from Darab et al. 1987].

\section{Methotrexate}

Although it is not a common human teratogen, methotrexate provides a useful example for this review as its pathogenetic mechanism is apparently different from those teratogens for which excessive cell death in regions of PCD plays a significant role. Methotrexate (MTX) is an antimetabolite whose principle biochemical mechanism of action is inhibition of DNA synthesis through competitive inhibition of folic acid reductase. This agent as well as another folic acid antagonist, aminopterin, when used unsuccessfully as abortifacients have resulted in the production of serious congenital malformation is humans (Milunsky, Graef \& Gaynor, 1968; Warkany, 1978). Cranial dysplasia and cleft palate have been described as fetal aminopterin effects (reviewed by Smith, 1982).

When acutely administered to mice on E9 as a $20 \mathrm{mg} \mathrm{kg}^{-1}$ i.p. dose, MTX induces median facial clefts (Fig. 10) (Darab, Sciote, Minkoff \& Sulik, 1987). In general, it has been concluded that this type 
of facial malformation results from a paucity of mesenchyme in the frontonasal prominence (FNP). Burk \& Sadler (1983) showed that cell death in the FNP midline mesenchyme and neural epithelium, in part, underlie diazo-oxo-norleucine (DON)-induced median facial clefts. The pathogenesis of MTXinduced median facial clefts, in addition, apparently involves fluid imbalance. Within $3 \mathrm{~h}$ after maternal treatment, evidence of distension of vessels in close proximity to the olfactory placodes was noted. This was followed within $24 \mathrm{~h}$ by the formation of large vascular blebs in the FNP and by distension of the neural tube (Fig. 10C). It was hypothesized that initial fluid imbalance, perhaps resulting from interference with osmoregulatory cells in extraembryonic capillary beds is in part responsible for the dysmorphogenesis. This effect, termed the oedema syndrome by Grabowski (1970), appears to underly the teratogenic effects of a number of agents including moderate hypoxia, dinitrophenol and trypan blue.

It is noteworthy that exposure of the same mouse strain $(\mathrm{C} 57 \mathrm{BL} / 6 \mathrm{~J})$ to retinoic acid at this same stage of development results in malformation primarily involving the visceral arch-derived lateral aspect of the head as opposed to the midline of the face. This is striking evidence that teratogens may act in different ways. In MTX-induced median facial clefts, distension of the neural tube and vasculature as opposed to effects on regions of PCD are the first notable signs of pathogenesis. It would, however, be of interest to determine whether some agents (DON?) might directly affect the $\mathrm{PCD}$ zone present in the frontonasal prominence midline and result in median facial clefting.

\section{Concluding remarks}

Our further understanding of abnormal developmental events promises to be greatly enhanced through the application of the knowledge gained from and technological advances utilized by modern developmental biologists. However, we must not forget the lessons from the past. Utilization of an old technique, supravital staining, has proven very useful in the investigation of the pathogenesis of craniofacial malformations. Additionally, the hypothesis put forward almost 20 years ago by Menkes and his associates that expansion of areas of PCD may have a role in teratogenesis, is again being explored and found to be applicable to the affects of some teratogens.

We feel that evidence in favour of expansion of regions of $P C D$ as a pathogenetic mechanism underlying malformations induced by ethanol and by RA is very convincing. The fact that FAS and RAE have different 'characteristic' phenotypes in the human suggests differences in accessibility of RA and ethanol to the embryo, differences in dose-response relationships, and possible differing concurrent effects by the teratogens. Another very important human teratogen, thalidomide, induces craniofacial malformations which are similar to those of RAE (Lammer \& Sulik, 1986). Menkes \& coworkers (1964) reported that thalidomide induced enlargement of normal necrotic areas in the retina and nasal epithelium of rabbit embryos. Preliminary evidence from our laboratories relative to thalidomide teratogenesis also suggests that malformations induced by thalidomide result from excessive cell death in regions of PCD.

A common target, i.e. cells in regions of PCD representing a developmental 'weak point', for some teratogens provides reason to expect interactive effects. Concurrent exposure to subthreshold teratogenic dose levels of more than one such agent should result in potentiation. Indeed, augmentation of teratogenic effects follows concurrent exposure to hyperthermia and vitamin A (Ferm \& Ferm, 1979).

Although studies of cell death specifically associated with regions of PCD have not been conducted for hyperthermia or radiation-induced teratogenesis and they have just been initiated for hypoxia, research along this line as previously mentioned, would be useful.

The fact that some teratogens may act by increasing cell death in regions of programmed cell death raises issues relative to the design of teratology tests. As these cells appear to be particularly vulnerable, it is important that cytotoxicity as it relates to teratogenesis is monitored with particular attention to the areas of PCD. In addition, attempts to impede malformations by using potential antinecrotic agents (e.g. methyl prednisolone, prostaglandin inhibitors) are indicated. We recommend utilization of supravital staining as a routine procedure in studies directed toward determining mechanisms of teratogenesis.

In conclusion, although we realize that many teratogenic mechanisms exist, we feel that excessive and premature cell death in regions of programmed cell death represents a phenomenon which is important, yet little appreciated. The selective sensitivity of these regions that change in position and extent with time provides clues for understanding critical periods for the induction of malformation.

We thank Ms Deborah Dehart for her excellent technical support and Ms Betty Stewart for typing this manuscript. This work was supported by NIH Grant DE07459.

\section{References}

Aвel, E. L. (1984). Fetal Alcohol Syndrome and Fetal Alcohol Effects. New York: Plenum Press. 
Ammann, A. J., Wara, D. W., Cowan, M. J., Barrett, D. J. \& Stechm, E. R. (1982). The DiGeorge syndrome and the fetal alcohol syndrome. Am. J. Dis. Child. 136, 906-908.

BacQ, Z. M. \& Alexander, P. (1961). Biochemical mechanisms for cellular effects - the enzyme release hypothesis. Fundamentals of Radiobiology. 2nd edn, pp. 263-279. New York: Pergamon Press.

Bannigan. J. \& Cotrell, D. (1984). Ethanol teratogenicity in mice: an electron microscopic study Teratology 30, 281-290.

Bannigan, J. G. \& Burke. P. (1982). Ethanol teratogenicity in mice: a light microscopic study. Teratology 26, 247-254.

Bockman, D. F. \& Kirby, M. L. (1984). Dependence of thymus development on derivatives of the neural crest. Science 223, 498-500.

BrENT. R. L. (1980). Radiation teratogenesis. Teratology 21, 281-298.

Bronsky, P. T., Johnston, M. C., Moore, N. B., Dehart, D. B. \& Sulik, K. K. (1987). Interference with nasal placodal invagination in hypoxia-induced cleft lip in mice. Am. J. Anat. (Submitted).

Bronsky, P. T., Johnston, M. C. \& Sulik, K. K. (1986). Morphogenesis of hypoxia-induced cleft lip in $\mathrm{CL} / \mathrm{Fr}$ mice. J. Craniofac. Genet. dev/ Biol. Suppl. 2, 113-128.

Burk, D. \& Sadler, T. W. (1983). Morphogenesis of median facial clefts in mice treated with diazo-oxonorleucine (DON). Teratology 27, 385-394.

Conen, M. M. (1982). An update on the holoprosencephalic disorders. J. Pediatr. 101, 865-869.

Cohlan, S. Q. (1953). Excessive intake of Vitamin A as a cause of congenital anomalies in the rat. Science 117 , 535-536.

Cook, C. S., Nowotny, A. Z. \& Sulik, K. K. (1987). Fetal alcohol syndrome: Eye Malformations in a Mouse Model. Arch. Ophthal. 105, 1576-1581.

Cook, C. S. \& Sulik, K. K. (1986). Sequential scanning electron microscopic analyses of normal and spontaneously occurring abnormal ocular development in C57B1/6J mice. SEM III, pp. 1215-1227.

Cook, C. S. \& Sulik, K. K. (1987). Keratolenticular dysgenesis (Peters' anomaly) as a result of acute embryonic insult during gastrulation. Pediatric Ophthal. Strabis. 25. 60-66.

Daft, P. A., Johnston, M. C. \& Sulik, K. K. (1986). Abnormal heart and great vessel development following acute ethanol exposure in mice. Teratology 33. 93-104

Daniel, M. A. \& Evans, M. A. (1982). Quantitative comparison of maternal ethanol and maternal tertiary butanol diet on postnatal development. J. Pharmacol. exp. Ther. 222, 294-300.

Darab, D., Sciote, J., Minkoff, R. \& Sulik, K. (1987). Pathogenesis of medial facial clefts in mice treated with methotrexate. Teratology 36, 77-86.

Dehaene, P., Samaille-Villette, C., Samaille, P-P., Crépin, G., Walbaum, R., Deroubaix, P. \& BlancGarin, A-P. (1977). Le syndrome d'alcoolisme foetal dans le Nord de la France, Rev. l'Alcool. 23, 145
Dencker, L., D'Argy, R., Danielsson, B. R. H., Ghantous, H. \& Sperber, G. O. (1987). Saturable accumulation of retinoic acid in neural and neural crest derived cells in early embryonic development. Dev. Pharmacol. Ther. 10, 212-223.

Dingle, J. T. (1961). Studies on the mode of action of excess Vitamin A: Release of a bound protease by the action of vitamin A. Biochem. J. 79, 509-512.

Dreost1, I. E. (1984). Interactions between trace elements and alcohol in rats. Ciba Foundation Symposium 105, 103-123.

Dreosti, I. E., Ballard, F. J., Belling, G. B., Record, I. R., Manuel, S. J. \& Hetzel., B. S. (1981). The effect of ethanol and acetaldehyde on DNA synthesis in growing cells and on fetal development in the rat. Alcoholism Clin. exp. Res. 5, 357-362.

Edwards, M. J. (1986). Hyperthermia as a teratogen: A review of experimental studies and their clinical significance. Teratogenesis, Carcinogenesis and Mutagenesis 6, 563-582.

Fell, H. B. \& Dingle, J. T. (1963). Studies on the mode of action of excess vitamin A: Lysosomal protease and the degradation of cartilage matrix. Biochem. J. 87 . 403.

Ferm, V. E. \& Ferm, R. R. (1979). Teratogenic interaction of hyperthermia and Vitamin A. Biol. Neonate 36, 168-172.

Geelan, J. A. G. (1979). Hypervitaminosis A induced teratogenesis. CRC, Crit. Rev. Toxicol. 6, 351-375.

Germain, M. A., Webster, W. S. \& Edwards, M. J. (1985). Hyperthermia as a teratogen: Parameters determining hyperthermia-induced head defects in the rat. Teratology 31, 265-272.

German, J. (1984). The embryonic stress hypothesis of teratogenesis. Am. J. Med. 76, 293-301.

Glücksmann, A. (1951). Cell death in normal vertebrate ontogeny. Biol. Rev. 26, 59-86.

Grabowskı, C. T. (1970). Embryonic oxygen deficiency A physiological approach to analysis of teratological mechanisms. Adv. Teratol. 4, 125-167.

Hale, F. (1933). Pigs born without eyeballs. J. Heredity 24, 105-106.

Hanson, J. W., Jones, K. L. \& Simith, D. W. (1976). Fetal Alcohol syndrome: experience with 41 patients. J. Am. Med. Assoc. 235, 1458-1460.

Hassler, J. A. \& Moran, D. J. (1986). Effects of ethanol on the cytoskeleton of migrating and differentiating neural crest cells: Possible role in teratogenesis. J. Craniofac. Genet. devl Biol. Suppl. 2. 129-136.

Hicks, S. P. \& D'Amato, C. (1966). Effects of ionizlng radiations on mammalian development. In Advances in Teratology, vol. 2 (ed. D. H. M. Woollam), pp. 196-250. London: Logos Press

ILIES, A. (1967). La topographie et la dynamique des zones nécrotıques normales chez l'embryon humain. Rev. Roum. d'Embryol. Cyt.-Série d'Embryol. 4, I, 51-84.

IlıEs, A. (1969). La topographie et la dynamique des zones nécrotiques normales chez l'embryon humain-II 
Rev. Roum, d'Embryol. Cyt.-Série d'Embryol, 6, 31-44.

Johnston, M. C. \& Sulik, K. K. (1984). Embryology of the Head and Neck. In Pediatric Plastic Surgery (ed. D. Serafin \& N. G. Georgiade), pp. 184-215. St. Louis: C. V. Mosby Co.

Juriloff, D. M., Sulik, K. K., Roderick, T. H. \& HoGAN, B. K. (1985). Genetic and developmental studies of a new mouse mutation that produces otocephaly. J. Craniofac. Genet. devl Biol. 5, 121-145.

Kalter, H. (1960). The teratogenic effects of hypervitaminosis $\mathrm{A}$ upon the face and mouth of inbred mice. A. N.Y. Acad. Sci. 85, 42-55.

KAY, E. D. (1987). Craniofacial dysmorphogenesis following hypervitaminosis $\mathrm{A}$ in mice. Teratology 35, $105-118$.

Kirby, M. L., Gale, T. F. \& Stewart, D. E. (1983). Neural crest cells contribute to normal aorticopulmonary septation. Science 220, 1059-1061.

Kochrar, D. M. \& Johnson, E. M. (1965). Morphological and autoradiographic studies of cleft palate induced in rat embryos by maternal hypervitaminosis A. J. Embryol. exp. Morph. 14, 223-238.

Lammer, E. J., Chen, D. T., Hoar, R. M., Agnish, N. D., Benke, P. J., Braun, J. T., Curry, C. J., Fernhoff, P. M., Grix, A. W., Jr., LotT, I. T., RiChARD, J. M. \& SUn, S. C. (1985). Retinoic acid embryopathy. N. Engl. J. Med. 313, 837-841.

LAmmer, E. J. \& Sulik, K. K. (1986). On a pattern of external ear malformation. Proc. Greenwood Genetic Center 5, 107-108.

Landaur, W. J. \& Sopher, D. (1970). Succinate, glycerophosphate and ascorbate as sources of cellular energy as antiteratogens. J. Embryol. exp. Morph. 24, 282-302.

Marks, R., Pearse, A. D., Hashimoto, T. \& Barton, S. (1983). Overview of mode of action of retinoids. In Retinoid Therapy (ed. Cunliffe \& Miller), pp. 91-99. Lancaster, U.K.: MTP Press.

Menkes, B., Deleanu, M. \& Illes, A. (1965).

Comparative study of some areas of physiological necrosis in the embryo of man, some laboratorymammals and fowl. Rev. Roum. d'Embryol. Cyt.-Série d'Embryol. 2, 161-171.

Menkes, B., Litvac, B. \& Illes, A. (1964). Spontaneous and induced cell degeneration in relation to teratogenesis. Rev. Roum. d'Embryol. Cyt.-Série d'Embryol. 1, 47-60.

Menkes, B., Sandor, S. \& Ilies, A. (1970). Cell Death in Teratogenesis. In Advances in Teratology (ed. D. H. Woollam), pp. 169-215. New York: Academic Press.

Millicovsky, G. \& Johnston, M. C. (1981). Hyperoxia and hypoxia in pregnancy: simple experimental manipulation alters the incidence of cleft lip and palate in CL/Fr mice. Proc. natn. Acad. Sci. U.S.A. 9, 4723.

Milunsky, A., Graef, J. W., Gaynor, M. F., JR (1968). Methotrexate-induced congenital malformations. $J$. Pediat. 72, 790-795.
Mirkes, P. E. (1985). Effects of acute exposure to elevated temperatures on rat embryo growth and development in vitro. Teratology 32, 259-266.

Morriss, G. M. (1973). The ultrastrauctural effects of excess maternal vitamin $\mathrm{A}$ on the primitive streak stage rat embryo. J. Embryol. exp. Morph. 30, 219-242.

Morriss, G. M. (1976). Abnormal cell migration as a possible factor in the genesis of vitamin-A-induced craniofacial anomalies. In New Approaches to the Evaluation of Abnormal Embryonic Development (ed. D. Neubert \& H. J. Merker), pp. 678-687. Stuttgart: Thieme.

Murakami, U., Kameyama, Y., Majima, A. \& Sakurai, T. (1962). Radiation malformations belonging to the cyclopia-arrhinencephalia-otocephalia group in the mouse fetus. J. Embryol. exp. Morph. 10, 64-72.

NaKatsuji, N. (1983). Craniofacial malformation in Xenopus laevis tadpoles caused by the exposure of early embryos to ethanol. Teratology 28, 299-305.

Nakatsuj, N. \& Johnson, K. E. (1984). Effects of ethanol on the primitive streak stage mouse embryo. Teratology 29, 369-375.

Ohкuma, S. \& Poole, B. (1981). Cytoplasmic vacuolation of mouse peritoneal macrophages and the uptake into lysosomes of weakly basic substances. J. Cell Biol. 90 , 656-664.

Olegard, R., Sabel, K-G., Aronsson, M., Sandin, B., Johansson, P. R., Carlsson, C., Kyllerman, M., Iversen, K. \& Hrbek, A. (1979). Effects on the child of alcohol abuse during pregnancy: retrospective and prospective studies. Acta Paediatr. Scand. 275, Suppl. 112.

Ouellette, E. M., Rosett, H. L., Rosman, N. P. \& WEINER, L. (1977). The adverse effects on offspring of maternal alcohol abuse during pregnancy. N. Engl. J. Med. 297, 528.

Pexieder, T. (1975). Cell death in the morphogenesis and teratogenesis of the heart. Adv. Anat. Embryol. Cell Biol. 6-99.

Pierro, L. J. \& Spiggle, J. (1967). Congenital eye defects in the mouse. I. Corneal opacity in C67B1 mice. J. exp. Zool. 166, 25-38.

Pierro, L. J. \& Spiggle, J. (1969). Congenital eye defects in the mouse. Il. The influence of litter size, litter spacing, and suckling of offspring on risk of eye defects in C67Bl mice. Teratology 2, 337-344.

Pleet, H., Graham, J. M. \& Smith, D. W. (1981). Central nervous system and facial defects associated with maternal hyperthermia at 4 to 14 weeks' gestation. Pediatrics 67, 785-789.

Poswillo, D. (1974). Otomandibular deformity: Pathogenesis as a guide to reconstruction. J. Maxillofac. Surg. 2, 64-72.

Rosa, F. W., Wilk, A. L. \& Kelsey, F. O. (1986). Teratogen update: Vitamin A congeners. Teratology 33, 355-364.

Ross, R. B. \& Johnston, M. C. (1972). Cleft lip and palate. Baltimore: Williams \& Wilkins.

RusSELL, L. B. (1950). X-ray induced developmental abnormalities in the mouse and their use in the analysis 
of embryological patterns. I. External and gross visceral changes. J. exp. Zool. 114, 545-602.

Russell, L. B. \& Russell, W. L. (1954). An analysis of the changing radiation response of the developing mouse embryo. J. cell. comp. Physiol. 43 Suppl. 1. 103-149.

SANDOR, S. (1968). The influence of ethyl alcohol on the developing chick embryo, II. Rev. Roum. Embryl. Cytol. Ser. Embryol. 5, 167.

Saunders, J. W., Gasseling, M. T. \& Saunders, L. (1961). Cellular death in morphogenesis of the avian wing. Devl Biol. 5, 147.

SchweICHEL, J. U. (1971). The influence of oral Vitamin A doses on interdigital necrosis in the limb bud of the rat. Teratology 4, 501 (Abst).

Schweichel, J. U. \& Merker, H. J. (1973). The morphology of various types of cell death in prenatal tissues. Teratology 7, 253-266.

Scotr, W. J., JR (1977). Cell death and reduced proliferative rate. In Handbook of Teratology, vol. 2 (ed. J. G. Wilson \& F. D. Fraser), pp. 81-98. New York: Plenum Press.

Shenefelt, R. E. (1972). Morphogenesis of malformations in hamsters caused by retinoic acid: Relation to dose and stage at treatment. Teratology 5, 103-118.

Shprintzen, R. J., Goldberg, R. B., Lewin, H. L., Sidoti, E. J., Berkman, M. D., Argamaso, R. V. \& YounG, D. (1978). A new syndrome involving cleft palate, cardiac anomalies, typical facies, and learning disabilities: velo-cardio-facial syndrome. Cleft Palate J. 15, 56-62.

Smiley, S. J., Speight, H. S., Johnston, M. C. \& Sulik, K. K. (1987). Malformations of the secondary palate induced by 13-cis retinoic acid. J. dent. Res. 66, 240 (abst.).

Smith, D. W. (1982). Recognizable Patterns of Human Malformation. Philadelphia: W. B. Saunders Co.

SmuTs, M. L. (1981). Rapid nasal pit formation in mouse stimulated by ATP-containing medium. J. exp. Zool. 216, 409-414.

Sokol, R. J., Miller, S. I., Debanne, S., Golden, N., Collins, G., Kaplan, J. \& Martier, S. (1981). The Cleveland NIAAA prospective alcohol-in-pregnancy study; the first year. Neurobehav. Toxicol. Teratol. 3 , 203.

Sporn, M. B., Roberts, A. B. \& Goodman, D. S. (eds) (1984). The Retinoids. New York: Academic Press.

Sulik, K. K. (1984). Critical periods for alcohol teratogenesis in mice, with special reference to the gastrulation stage of embryogenesis. In Ciba Foundation Symposium no. 105, pp. 124-141. London: Pitman Books Ltd.

Sulik, K. K. \& Dehart, D. B. (1988). Retinoic acidinduced limb malformations resulting from apical ectodermal ridge cell death. Teratology (in press).

Sulik, K. K. \& Johnston, M. C. (1982). Embryonic origin of holoprosencephaly: Interrelationship of the developing brain and face. Scanning Electron Microsc. 1, 309-322.
Sulik, K. K. \& Johnston, M. C. (1983). Sequence of developmental alterations following acute ethanol exposure in mice. Craniofacial features of the fetal alcohol syndrome. Am. J. Anat. 166, 257-269.

Sulik, K. K., Johnston, M. C., Ambrose, L. J. H. \& Dorgan, D. (1979). Phenytoin (Dilantin) induced cleft lip: A scanning and transmission electron microscopic study. Anat. Rec. 195, 243-255.

Sulik, K. K., Johnston, M. C., Daft, P. A. \& Russell, W. E. (1986). Fetal alcohol syndrome and DiGeorge anomaly: critical ethanol exposure periods for craniofacial malformations as illustrated in an animal model. Am. J. Med. Genet. 2, 191-194.

Sulik, K. K., Johnston, M. C. \& Dehart, D. B. (1987a). Potentiation of programmed cell death by 13cis retinoic acid: A common mechanism for early craniofacial and limb malformations? Teratology 35. $32 \mathrm{~A}$.

Sulik, K. K., Johnston, M. C., Smiley, S. J., Speight, H. S. \& JARVIS, B. E. (1987b). Mandibulofacial dysostosis (Treacher Collins Syndrome): A new proposal for its pathogenesis. Am. J. Med. Genet. 27. $359-372$.

Sulik, K. K., Johnston, M. C. \& WebB, M. A. (1981). Fetal alcohol syndrome: Embryogenesis in a mouse model. Science 214, 936-938.

Sulik, K. K., Lauder, J. M. \& DeharT, D. B. (1984). Brain malformations in prenatal mice following acute maternal ethanol administration. Int. J. devl Neuroscience 2, 203-214.

Sulik, K. K. \& Schoenwolf, G. C. (1985). Highlights of craniofacial morphogenesis in mammalian embryos as revealed by scanning electron microscopy. Scanning Electron Microsc. IV 1735-1752.

Sulik, K. K., Webster, W. S., Johnston, M. C. \& Cook, C. S. (1987c). Programmed cell death in the embryo: A "blueprint" of malformation patterns. Proc. Greenwood Genet. Center 7, 127-128 (abst.).

Thayer, J. M., Adams, E. A., Effmann, E. L. \& Sulik, K. K. (1987). Critical period for 13-cis retinoic acid induced aortic arch malformations precedes initial formation of the 4th visceral arch vessel. Teratology 35 , $32 \mathrm{~A}$.

Thorogood, P. V., Smith, L., Nicol, A., McGinty, R. \& GARROD, D. (1982). Effects of vitamin A on the behavior of migratory neural crest cells in vitro. J. Cell Sci. 57, 331-350.

Trasler, D. G. (1968). Pathogenesis of cleft lip and its relation to embryonic face shape in $\mathrm{A} / \mathrm{Jax}$ and $\mathrm{C} 57 \mathrm{Bl}$ mice. Teratology 1, 33-50.

Trasler, D. G. \& Leong, S. (1982). Mitotic index in mouse embryos with 6-aminonicotinamide induced and inherited cleft lip. Teratology 25, 259-267.

Trocha, P. J. \& Catravas, G. N. (1980). Variation in cyclic nucleotide levels and lysosomal enzyme activities in the irradiated rat. Rad. Res. 83, 658.

Von Ardenne, M. \& Krüger, W. (1979). Local tissue hyperacidification and lysosomes. In Lysosomes in Applied Biology and Therapeutics, vol. 6 (ed. J. T. Dingle, P. J. Jacques, \& I. H. Shaws), pp. 161-194. Amsterdam: North Holland Publishing Co. 
Walker, B. E. \& Crain, B. (1960). Effects of hypervitaminosis $\mathrm{A}$ on palate development in two strains of mice. Am. J. Anat. 107, 49-58.

Walsh, D. A., Klein, N. W., Hightower, L. E. \& EDwards, M. J. (1985). Heat shock and thermotolerance during early rat embryo development. Teratology 31, 30a.

Warkany, J. (1978). Aminopterin and methothexate: folic acid deficiency. Teratology 17, 353-358.

WeBSTER, W. S. (1988). Alcohol as a teratogen: A teratologist's perspective of the fetal alcohol syndrome. In Human Metabolism of Alcohol (ed. R. D. Batt \& K. Crow). Cleveland: CRC Press (in press).

WeBster, W. S. \& EDWARDS, M. J. (1984). Hyperthermia and the induction of neural tube defects in mice. Teratology 29, 417-425.

Webster, W. S., Germain, M. A. \& Edwards, M. J. (1985). The induction of microphthalmia, encephalocele, and other head defects following hyperthermia during the gastrulation process in the rat. Teratology 31, 73.

Webster, W. S., Germain, M. A., Lipson, A. \& Walsh, D. (1984). Alcohol and congenital heart defects: An experimental study in mice. Cardiovas. Res. 18, 335-338.

Webster, W. S., Johnston, M. C., Lammer, E. J. \& Sulik, K. K. (1986). Isotretinoin embryopathy and the cranial neural crest: An in vivo and in vitro study. J. Craniofac. Genet. devl Biol. 6, 211-222.

Webster, W. S., Walsh, D. A., Lipson, A. H. \& McEwEN, S. E. (1980). Teratogenesis after acute alcohol exposure in inbred and outbred mice. Neurobehav. Toxicol. Teratol. 2, 227-234.

Webster, W. S., WALSh, D. A., McEwen, S. E. \& Lipson, A. H. (1983). Some teratogenic properties of ethanol and acetaldehyde in C57B1/6J mice: Implications for the study of the fetal alcohol syndrome. Teratology 27, 231-243.

Wiley, M. J., Cauwenbergs, P. \& Taylor, I. M. (1983). Effects of retinoic acid on the development of the facial skeleton in hamsters: Early changes involving cranial neural crest cells. Acta Anat. 116, 180-192.

Willhite, C. C., Hill, R. M. \& Irving, D. W. (1986). Isotretinoin-induced craniofacial malformations in humans and hamsters. J. Craniofac. Genet. devl Biol. Suppl. 2, 193-209.

Wills, E. D. \& WiLkinson, A. E. (1966). Release of enzymes from lysosomes by irradiation and the relation of lipid peroxide formation to enzyme release. Biochem. J. 99, 657.

YIP, J. E., KoKICH, V. G. \& Shepard, T. H. (1980). The effect of high doses of retinoic acid on prenatal craniofacial development in Macaca nemestrina. Teratology 21, 29-38. 
